\title{
Effecten van fusies en acquisities op aandelenrendementen: theorie en empirie
}

\author{
Dr. R. A. I. van Frederiks/ust, Drs. V. van der Wal, Dis. H. Westdijk
}

\section{Inleiding}

In dit artikel worden de resultaten gepresenteerd van een onderzock naar fusies en acquisities van Nederlandse ondernemingen genoteerd aan de Amsterdamse Effectenbeurs in de periode 1954-1997. Onder cen fusic of acquisitic wordt iedere economische transactie verstaan, die van twee of meer ondernemingen één maakt (Weston en Copeland, 1992). Bij fusies gaat het om min of meer gelijkwalardige partners, terwijl bij acquisities veclal de grotere onderneming (de bieder) de kleinere onderneming (het doclwit) overneemt. In het vervolg zal er geen onderscheid worden gemaakt tussen de beide begrippen en zullen ze door elkaar worden gehanteerd. Het doel van dit artikel is een kort overzicht en een synthese te geven van eerdere onderzoeken naar de achterliggende theorieën over het rendement van fusies en acquisities. Zo onderzochten Berkovitch en Narayanan (1993) al de motieven hubris, agency en synergie. Schwert (1994) zocht de verklaring in de markup pricing en andere onderzoekers noemden terloops mogelijke theorieën die als verklaring dienden voor hun financiële uitkomsten naar fusies en acquisities. In dit artikel zijn deze theorieën en hypotheses geïntegreerd en

Dr. R. A. I. van Frederikslust is universitair hoofddocent in Corporate Finance aan de Faculteit Bedrijfskunde van de Erasmus Universiteit Rotterdam.

Drs. $V$. van der Wal studeerde bedrijfskunde aan de Erasmus Universiteit Rotterdam en is momenteel werkzaam bij PricewaterhouseCoopers N.V. Management Consultants.

Drs. H. Westdijk studeerde bedrijfskunde aan de Erasmus Universiteit Rotterdam en is momenteel werkzaam bij KPMG N.V. Management Services. getoetst aan de situatie in Nederland. Het artikel is als volgt opgebouwd: eerst zullen in paragraaf 2 de heersende waardecreërende en herverdelingstheorieën aangaande fusies en acquisities worden besproken. Daarna worden in paragraaf 3 de geselecteerde data toegelicht en de gevolgde methodologie uiteengezet. Voorts worden in paragraaf 4 de resultaten van fusies en acquisities geanalyseerd voor de aandeelhouders van de bieders en de doelwitten. Vervolgens wordt vanuit de waardecreërende en de herverdelingstheorieën een regressiemodel afgeleid ter verklaring van de rendementsresultaten van de fuserende partijen, waarbij tevens rekening wordt gehouden met de gevolgde biedingstrategie. Deze modellen worden daarna geschat uit en getoetst aan waarnemingen betreffende een steekproef van Nederlandse fusies en acquisities uit de periode 1954-1997. Afgesloten wordt in paragraaf 5 met een samenvatting en de belangrijkste conclusies uit het onderzoek.

\section{Waardecrë̈rende en herverdelingstheoricën}

Er wordt in dit artikel een onderscheid gemaakt naar de waardecreërende en herverdelingstheorieën. Bij de waardecreërende theorieën speelt het synergiemotief de hoofdrol, terwijl bij de herverdelingstheorieën agency-problemen of hubris een rol kunnen spelen.

\subsection{Waardecreërende theorië̈n}

Een fusie of acquisitie is economisch zinvol als het geheel meer is dan de som der delen oftewcl als er sprake is van synergie. De meerwalarde kan onder meer worden behaald bij 
horizontale fusies door: schaalvoordelen bij productie en distributie, toegang tot nieuwe markten, gezamenlijk hoofdkantoor, verwijdering van inefficiënt management, grotere financiële mogelijkheden en gezamenlijke immateriële activa (patenten, octrooien, licenties). Bij verticale fusies waar men de bedrijfskolom verkort, heeft men eveneens de mogelijkheid om te besparen op inkopen en kan er door efficiënte communicatie gerichter geproduceerd worden naar gelang de marktontwikkeling. Een andere door Sirower (1997) geformuleerde definitie voor het begrip synergie luidt als volgt:

Synergie is een toename van het concurrentievermogen en de daaruit voortvloeiende cashflows die groter zijn dan beide bedrijven zelfstandig naar verwachting zullen bereiken.

Sirower stelt dat waardecreërende fusies ondanks de soms goede bedoelingen van het management zeldzaam zijn. Een fusie is pas waardevol als de synergie (extra meerwaarde) de gemaakte fusiekosten inclusief de controlepremie overtreft. Andere onderzoekers (Healy, Palepu en Ruback, 1992) zijn positiever en komen tot de conclusie dat in de post-fusiefase meestal significante verbeteringen zijn in de cashflow ten opzichte van andere ondernemingen in de industrie.

\subsection{Herverdelingstheorieën}

Een fusie is niet waardevol wanneer de extra cashflow lager is dan de controlepremie en/of zelfs lager is dan de integratiekosten. Er zijn twee hoofdvisies die de oorsprong van deze fusies proberen te verklaren. Deze visies zijn de hubrisen de agency-theorie.

De hubris-theorie stelt dat managers streven naar synergie met als doel de winst voor aandeelhouders te optimaliseren. Helaas lijden managers aan zelfoverschatting, waardoor de waarde van de synergie achterblijft. Uit onderzoek (Roll, 1986) blijkt dat bij deze fusies meestal wel synergie optreedt, maar dat deze door te positieve voorcalculaties van het management te laag is om de controlepremie goed te maken.

De agency-theorie stelt dat de belangen van de aandeelhouders c.q. eigenaars niet parallel lopen aan die van het management. De scheiding tussen kapitaal en leiding brengt managers ertoe vooral het eigen belang na te streven. Als reden voor een fusie kan het zogenaamde Empire Building worden opgevoerd dat stelt dat managers streven naar een zo groot mogelijke onderneming (Mueller, 1989). Een grote onderneming geeft meer status en uit onderzoek blijkt dat het salaris positief gecorreleerd is aan de grootte van de onderneming. Tevens biedt een grote onderneming de mogelijkheid tot meer emolumenten en kan het mogelijk managementsfalen uit het verleden verbloemd worden. Een onderdeel van de agency-theorie is de theorie van de vrije cashflow. De vrije cashflow is het vermogen waarvoor geen rendabele investeringen meer aanwezig zijn in de onderneming. Deze cashflow die over het algemeen in de (vrije) reserves is terug te vinden, zou als dividend aan de aandeelhouders uitgekeerd kunnen worden. Deze vrije reserves worden volgens deze theorie echter gebruikt om fusies te bewerkstelligen die vooral de belangen van het bestuur dienen. De resultaten van deze fusies leiden zelden tot een verbetering in de cashflow van de betrokken ondernemingen (Morck, Schleifer en Vishny, 1990).

De speltheorie is een onderdeel van de agen$c y$-problematiek die wordt toegepast om fusiegolven te verklaren. Op het moment dat een leider c.q. concurrent besluit om te gaan fuseren zal men moeten besluiten of men deze aanval op de eigen marktpositie moet beantwoorden met een zelfde strategie. Het probleem voor de bestuurders is dat men niet weet wat de drijfveren van de concurrent precies zijn en of dit financieel een verstandige zet was. Wanneer men niet tot een fusie overgaat, terwijl die van de concurrent waardecreërend was, loopt men het risico zelf het doelwit te worden van een volgende overname (Schenk, 1996). Volgens deze theorie zal men ondanks het feit dat de mogelijke winst na een fusie lager kan zijn dan de winst die men zelfstandig zou kunnen behalen, toch overgaan tot een fusie om de spijt te minimaliseren. Mochten de resultaten van een fusie erg tegenvallen dan is er nog altijd het excuus dat men niet anders handelde dan andere bestuurders uit de bedrijfstak. Op deze manier wordt hun reputatie nauwelijks geschaad. Zo zei Keynes al in 1936: 'It is better for reputation to fail conventionally than succeed unconventionally.'

De fusies die volgen na de leider hebben een kleinere slagingskans. Door de beperkte voorbereidingstijd die ontstaat door de concurrentie op de overnamemarkt zal het strategisch traject dat benodigd is voor de bepaling van de verwachte 
slrkergie ingekort worden. Deze "geforcerde fusies" zullen door de aandeelhouders nict hoog gewaardeerd worden zodat als enige belanghebbende het management herkend kan worden. De controlepremie zal gedurende de vermindering van de mogelijke fusiepartners stijgen doordat speculanten aandelen van te verwachten doelwitten zullen kopen. Tevens zullen ondernemingen die geen doelwit willen worden beschermingsconstructies ereëren die alleen geslecht kunnen worden door middel van hoge controlepremics die alle synergie te niet doen. Wanneer er geen middelen meer zijn om te kumnen fuseren zal de golf zich terugtrekken. Veelal begint dan de periode van afstoten en reorganiseren tot de impasse weer wordt doorbroken door cen nieuwe fusieleider. Net als bij de agency-theorie streeft men niel naar maximalisatie van de waarde voor de aandeelhouders. Het doel van het management bij de speltheorie is eenduidig en betreft de bescherming van de cigen reputatie.

Deze micro-economische verklaring van fusiegolven wordt door De Jong (1998) niet gevolgd. Een fusic wordt nict uitsluitend aangegalan uit hoofde van onzekerheidsreductie. Een voorsprong in organisatie en innovatic buit men uit ongeacht de hicrmee samenhangende onzekerheid. Het feit dat tijdens een concentratie c.c. fusiegolf niet alle ondernemingen participeren komt niet overeen met de speltheoric. Tevens laten bepaalde bedrijfstakken geen enkele coneentratietendens zien ondanks hun oligopolide structuur. De Jong verklaart fusiegolven door middel van de marktheoric. Een onderneming gaat door vier verschillende fases namelijk de pionicrfase, de expansiefase, de rijpheidfase en de teruggangfase. Op het moment dat een onderneming of de bedrijfstak is beland in de rijpheidfase ontstaat er overcapaciteit en een versterkte prijsconcurrentie samengaand met lage marges. In deze fase zullen ondernemingen uit kostenbesparende overwegingen horizontale fusies aangaan. Bij aanhoudende stagnatie zal men tevens proberen nieuwe afzetgebieden te bereiken door buitenlandse overnames. Wanneer een onderneming in de teruggangfase geraakt, worden bedrijfsonderdelen afgestoten en verkocht om kapitaal te vergaren voor veelbelovende restmarkten of verliesdekking. Een fusiegolf wordt aldus gezien als een natuurlijk proces.

\section{Data en methodologie}

In dit onderzoek worden de koersreatieties bestudeerd van fusiepartners die beiden genoteerd waren aan de Amsterdamse Effectenbeurs. De onderzocksperiode loopt vanaf 1954 tot en met 1997 en betreft 101 fusies. Aan de hand van deze fusies is de reactie van de markt bestudeerd op het moment van een fusieaankondiging. Tevens is getracht een brug te slaan tussen do fusieverklarende theorieën en de situatic in Nederland. Een koersstijging duidt op een positieve verwachting van de markt op fusies als middel om het rendement te vergroten middels aandelenparticipatic in de nieuwe combinatic. Uit voorafgaand onderzoek blijkt echter dat de aankondiging van een fusic geregeld leidt tot negatieve kocrsreactics. Vooral bij de biedende onderneming leidt een fusicbericht vaak tot dalende aandeelkoersen. Uit cen onderzock van De Bruin en Van Frederikslust (1994) blijken de koersen van bieders gemiddeld met 1,2 procent te dalen als reactie op een fusie. Ook een onderzoek van Bosveld. Meyer en Vorst (1997) naar 122 fusies in Nederland laat een lichte daling zien van de koers van de bieder. De markt waardeert fusies blijkbaar anders dan de managers van de biedende onderneming.

\section{I Data selectie}

De in het onderzoek opgenomen ondernemingen zijn alle minstens 1 jaar voor het overnamebod aan de beurs in Nederland genoteerd geweest. In de steekproef zijn 202 ondernemingen opgenomen over de periode 1954-1997 die betrokken waren bij een fusic. In het onderzoek zijn geen financiële instellingen betrokken zoals banken en verzekeringsmaatschappijen. Fusies tussen meer dan twee bedrijven zijn evenals fusies waarbij gegevens ten aanzien van het bod ontbraken nict opgenomen. Ook fusies waarbij geen handel toegestaan was in aandelen van het doelwit in verband met een belangrijke (fusie-)aankondiging zijn weggelaten uit het onderzock. Fusies aangegaan met buitenlandse ondernemingen zijn eveneens uitgesloten. Van de ruim 170 fusies bleven er uiteindelijk 101 over. In fïguur la is een verdeling opgenomen van de fusies naar bedrijfstak en in figuur 1 b naar periode. 


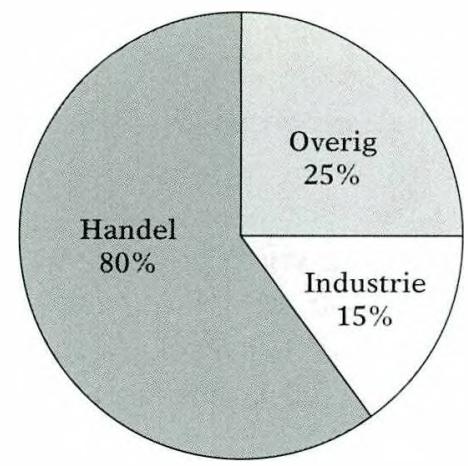

Figuur la: Fusies naar bedrijfstak

De marktindexcijfers op dagbasis zijn beschikbaar gesteld door het CBS. De index die gebruikt is over de periode 1954-1979 is de ANPCBS beursindex naar bedrijfstak. Vanaf 1980 is gekozen voor de vervanger van de ANP-CBS beursindex naar bedrijfstak en dit is de koersindex naar bedrijfstak.

\subsection{Methodologie}

Onderzoek naar het rendement van fusies en overnames is in twee categoricën te verdelen namelijk ex ante- en ex post-onderzoek. Ex postonderzoeken bestuderen de financiële prestatics van de ondernemingen nadat een fusie heeft plaatsgevonden. Deze onderzoekmethode wordt uitgevoerd over enkele jaren en de invloed van de fusie op de toekomstige resultaten wordt achterhaald via jaarrekeningen en de koersen van de bieder of de nieuwe combinatie. Een probleem van deze onderzoeksmethode is dat men een grote onderzoeksperiode gebruikt die verstoord kan worden door factoren die buiten de invloed van de fusie vallen. Jaarrekeningen worden hoogstens eens per kwartaal bekendgemaakt en kunnen gemanipuleerd worden, waardoor de werkelijke resultaten van een fusie niet zichtbaar zijn. Dit onderzoek zal middels een ex anteonderzoek uitgevoerd worden. Een ex ante- of eventstudie bestudeert de reactic van de beurs op een voorgenomen fusie. De koers van de bieder en het doelwit vormen een verwachting van de aandeelhouders ten aanzien van de toekomstige rendementen. De beurs beoordeelt de fusie als het ware vooraf (ex ante). De prestatie van een fusie wordt dus geanalyseerd middels de verwachting van de markt die tot uitdrukking komt in de koersen van de betrokken ondernemingen rond de aankondiging van het openbaar bod. Deze methode prevaleert boven het ex post-onderzoek dat gebruikmaakt van boekhoudkundige gegevens on twee redenen (Sirower, 1997). Ten eerste blijkt dat de markt managementbeslissingen op basis van verwachte cashflow op lange termijn evaluecrt en niet op basis van boekhoudkundige kengetallen die betrekking hebben op de korte termijn. In het biedingsbericht worden deze boekhoudkundige kengetallen meestal gepubliccerd. Ten tweede kunnen bockhoudkundige rendementen zoals eerder genoemd, worden gemanipuleerd en worden verstoord door externe factoren.

In eventstudies wordt de kapitaalmarkt als een efficiënte markt gezien, waarbij alle informatie die openbaar beschikbaar is direct wordt verwerkt in de koers van ondernemingen. Dit staat bekend als de efficiënte markt hypothese. Het bchalen van een abnormaal rendement is alleen mogelijk met

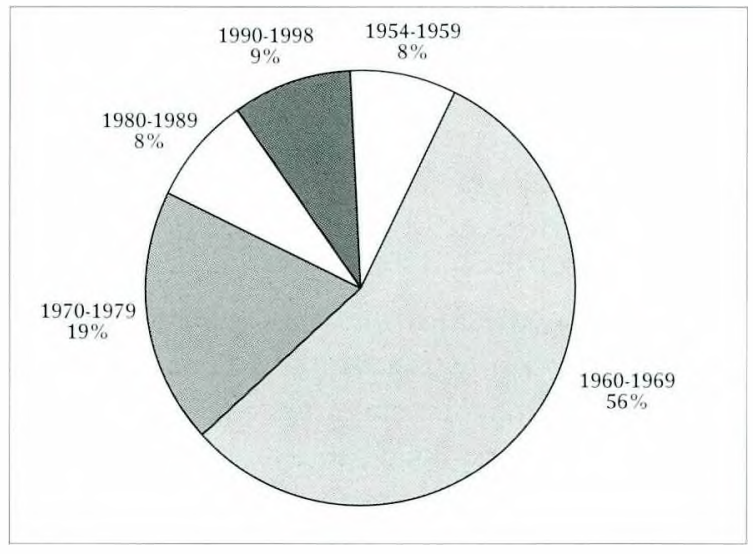

Figum Ib: Fusies natr periode

behulp van deze beschikbare informatie. De koers van een onderneming geeft dan een reëel beeld van de actuele waarde van een onderneming op basis van alle aanwezige relevante informatie die op dat moment beschikbaar is. De verwerking van informatie in de koers wordt ook wel informationele efficiëntie genoemd. Deze informationele efficiëntie wordt gemeten naar de snelheid dat informatie verwerkt wordt $\mathrm{en}$ de soort of kwaliteit van deze informatie (Weston en Copeland, 1992).

In dit artikel wordt gebruikgemaakt van de semi-sterke vorm van de Efficiënte Markt Hypothese; hierbij wordt uitgegaan van de veronderstelling dat alle openbaar beschikbare informatie die relevant is direct wordt verwerkt in de koers van de betreffende onderneming. De keus om in 
deze studic de Efficiënte Markt Hypothese als uitgangspunt te nemen komt tevens uit de bevindingen van andere onderzoeken die deze suceesvol hebben toegepast. Uit eerder onderzoek is namelijk herhaaldelijk vastgesteld dat de koersen zeer gevoclig zijn voor nieuwe informatie.

Tevens zijn professioncle fondsen en andere beleggers gezamenlijk niet stelselmatig in staat geweest met de beschikbare informatie een hoger rendement te behalen dan het marktgemiddelde (Schenk. 1994).

\subsection{Het Cumulatieve Abnormale Rendement}

Eventstudies bestuderen de genormaliseerde beurskoersen van de bieder en het doelwit rond het tijdstip dat deze wordt alangekondigd. Het abnormale c.q. buitengewone rendement is het rendement dat behaald wordt boven het normale (verwachte) rendement dat behaald zou worden zonder een aankondiging tot fusic. Het rendement dat wordt behaald na een openbaar bod zal echter eerst gecorrigeerd en geïnterpreteerd moeten worden. On het buitengewoon resultaat te meten wordt er gebruikgemaakt van de Market Model Method (Weston en Copeland, 1992. Van Frederikslusi, 1994. Sirower, 1997).

De koersreactie die rond het openbaar bod platsvindt wordt door gebruik van deze methode gecorrigeerd, zodat het abnormale rendement dat samenhangt met de fusie kan worden herkend.

Het marktmodel ziet er als volgt uit:

(1) $R=\alpha+\beta R_{-}+\varepsilon$ waarin:

$R=$ het rendement van een aandecl $j$ op tijdstip $t$

$\alpha=$ de constante van het model

$\beta=\operatorname{COV}\left(R_{n}, R_{m}\right) / \operatorname{VAR}\left(R_{m t}\right)$ de betafactor van aandecl/

$R_{m t}=$ rendement van de markt op tijdstip $t$

$\varepsilon_{t}=$ de storingsterm op tijdstip / van aandeel $j$ met

$\mathrm{E}\left(\varepsilon_{\mathrm{s}}\right)=0, \operatorname{VAR}(\varepsilon)=\sigma^{2}$ en

$\operatorname{COV}(\varepsilon, \varepsilon)=0$ als $i \neq j$

De parameters van het model $\alpha$ en $\beta$. worden geschat op basis van waarnemingen uit de steekproef met behulp van de methode der kleinste kwadraten. Deze schatting is verricht over een periode van -200 dagen tot -41 handelsdagen voor het bod. De periode loopt niet geheel tot het bod omdat de koersen vaak een maand tevoren al oplopen (pre-bid runup). Het rendement van de markt is bepaald door middel van de CBS-koersindices.
(2) $A R=r-a-b R$

Ilet abnormal rendement (AR) is het rendement $r$ behaald tijdens de fusieperiode verminderd met het geschatte rendement op basis van het verleden. Ilet rendement tijdens de fusieperiode is berekend op basis van dagkoersen. In dit model zijn $a$ en $b$ schattingen van de parameters $\alpha$ en $\beta$ uit het marktmodel. $A R_{u}$ is het abnormaal rendement in de analyseperiode die in dit onderzock loopt van 40 dagen voor het bod tot 5 dagen na het bod. Bij een fusieaankondiging na sluiting van de beurs is dag () verplaatst naar de cerste handelsdag.

Om het gemiddekde abnormale rendement te berekenen op $\ell=0$ van bijwoorbecld $\mathrm{N}$ doelwitten $\mathrm{en} / \mathrm{of}$ bieders wordt onderstaande formule gebrukt.

(3) $A R_{0}=\frac{1}{1} \sum A R_{0}$

Door middel van een Student-t-toets (Brown en Warner, 1980) wordt nagegaan of dit extra rendement al dan niet aan het tocval te wijten is. Daarnaast is voor de analyseperiode tevens het cumulatieve gemiddelde abnormale rendement (CAR) rond de fusiedatum van bijvoorbeeld $(-40,+5)$ gemeten met de volgende formule:

(4) $\mathrm{CAR}(-40,+5)=\sum A R_{\text {, }}$

en getoetst met een soortgelijke Student- $t$-toets (Brown en Warner. 1980).

Het abnormale rendement voor beide fusiepartners TCAR op tijdstip $t$ wordt berekend als het gewogen gemiddelde van het abnormale rendement van het doe/wit en de bieder met als wegingsfactor de relatieve marktkapitalisatic van het doelwit en de bieder op $t=-40$. Door middel van deze weging wordt een correctie gemaakt voor het verschil in grootte tussen de bieders en de doelwitten. Zonder deze correctie zou het rendement van de combinaties onevenredig groot zijn, omdat naar verwachting het rendement van de doelwitten velen malen groter is dan dat van de bieders.

\section{Resultaten van fusies en acquisities}

In deze paragraaf worden de resultaten van de fusies en acquisities geanalyseerd voor de aandeelhouders van de bieders en de doelwitten. Vervolgens wordt vanuit de waardecreërende en de herverdelingstheorieën een regressiemodel afgeleid ter verklaring van de rendementsresultaten van de fuserende partijen, warabij tevens 
rekening wordt gehouden met de gevolgde biedingsstrategie. Deze modellen worden daarna geschat uit en getoetst aan waarnemingen betreffende de steekproef van Nederlandse fusies en acquisities uit de periode 1954-1997.

\subsection{CAR doelwitten en bieders}

Hieronder zal eerst het CAR van de doelwitten en daarna dat van de bieders worden behandeld.

\section{I.1 Overzicht CAR doelwitten}

Om de significantie van het cumulatieve gemiddelde abnormale rendement te toetsen is voor de verschillende periodes een $T$-toets uitgevoerd. De significantie is bepaald door middel van de eerder genoemde toetsgrootheid $T$ (Brown en Warner, 1980). Aangezien positieve waarden te verwachten zijn, is gekozen voor een rechts-eenzijdige toets. Deze verwachte positieve waarde hangt samen met het overnamebod dat de bieders doen om alle aandelen in bezit te krijgen. In tabel 1 staan de rendementen voor de doelwitten over de vijf gekozen periodes, nadat door middel van een uitgebreide uitbijteranalyse twaalf ondernemingen zijn verwijderd vanwege te hoge z-scores en hun sterk verstorende invloed op met name de CARs.

Tabel 1: Rendement doelwit in de verschillende tijdsperiodes

\begin{tabular}{lll} 
Tijdsperiode & CAR & T-wcarde \\
\hline CAR $(-1.0)$ & $11.94 \%$ & $6.623^{*}$ \\
CAR $(-1 .+5)$ & $11.02 \%$ & $5.490^{*}$ \\
CAR $(-10,+5)$ & $16.76 \%$ & $6.578^{*}$ \\
CAR $(-20 .+5)$ & $19.18 \%$ & $6,776^{*}$ \\
CAR $(-40,+5)$ & $22.59 \%$ & $7,488^{*}$
\end{tabular}

* siginificant bij een niveau van 5 procent

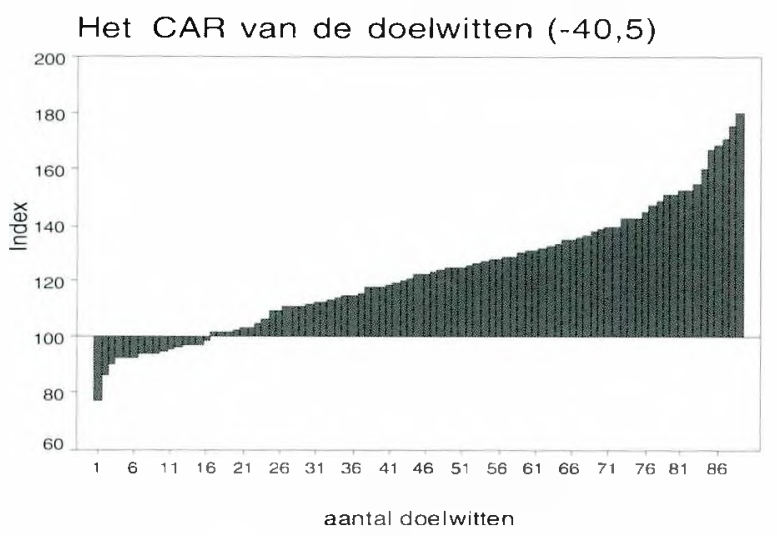

Figun 2: Distributie van het geindexeerde CAR voor de doelwitten in de steekproef

Uit deze waarden blijkt dat het CAR voor alle periodes significant is op het niveau van vijf procent. Om een beter inzicht te verkrijgen in de verdeling van het CAR over de steekproef is deze grafisch weergegeven voor de gehele onderzoeksperiode in figuur 2 . Zie ook tabel 2 voor de descriptives van het CAR van de doelwitten.

In tabel 3 volgen de resultaten van enkelc onderzoeken naar het CAR van doelwitten rond het bekendmaken van de fusie.

\subsubsection{Overzicht CAR bieders}

Om de significantie van het cumulatieve gemiddelde abnormale rendement te toetsen over de verschillende periodes voor de bieders is de T-

Tabel 2: Descriptives van het CAR van de doelwitten

\begin{tabular}{lll}
\hline & $\begin{array}{l}\text { CAR } \\
\text { kleiner dan mul }\end{array}$ & $\begin{array}{l}\text { CAR } \\
\text { groter dan mul }\end{array}$ \\
\cline { 2 - 3 } Aantal & 16 & 73 \\
Minimum CAR & $-22.40 \%$ & $1.78 \%$ \\
Maximum CAR & $-0.87 \%$ & $79.73 \%$ \\
Gemiddeld & $-6.61 \%$ & $29.04 \%$ \\
Medialan & $-5.41 \%$ & $26.59 \%$ \\
\hline
\end{tabular}

Tabel 3: Overzicht onderzoeksresultaten naar het rendement van het doelwit

\begin{tabular}{|c|c|c|c|c|c|}
\hline Onderzoek & $\begin{array}{l}\text { Steekproef } \\
\text { Periode }\end{array}$ & $\begin{array}{l}\text { Steekproef } \\
\text { grootte }\end{array}$ & Land & Periode & CAR doelwit \\
\hline $\begin{array}{l}\text { Van Frederikslust, Van der Wal en } \\
\text { Westdijk (2000) }\end{array}$ & $1954-1997$ & 101 & $\mathrm{NL}$ & $(-1,0)$ & $11.94 \%$ \\
\hline De Bruijn en Van Frederikslust (1994) & $1980-1993$ & 39 & NL & $(-1,+1)$ & $28.04 \%$ \\
\hline Bosveld, Meyer en Vorst (1997) & $1970-1994$ & 122 & NL & $(-1 .+1)$ & $9.93 \%$ \\
\hline Scliwert (1996) & $1975-1991$ & 1814 & VS & $(-1,0)$ & $10.1 \%$ \\
\hline Berkovitch en Narayanan (1993) & $1963-1988$ & 330 & VS & $(-5,+5)$ & $31.5 \%$ \\
\hline
\end{tabular}


Tabel 4: Rendement voor de bieders in de verschillende tijdsperiodes

\begin{tabular}{lll}
\hline Tijalsperiode & CAR & T-waalde \\
\hline CAR $(-1,0)$ & $0.25 \%$ & 0.998 \\
CAR $(-1,+5)$ & $-0.81 \%$ & -1.324 \\
CAR $(-10 .+5)$ & $-0.21 \%$ & -0.299 \\
CAR $(-20 .+5)$ & $0.06 \%$ & 0.064 \\
CAR $(-40 .+5)$ & $0.94 \%$ & 0.780
\end{tabular}

toets uitgevoerd. De significantie wordt getoetst door middel van de eerder genoemde toetsgrootheid $\mathrm{T}$. Bij de doelwitten waren hoge positieve rendementen te verwachten. maar bij de bieders is dit niet zo zeker. Vandaar dat hier gekozen is voor een tweezijdige toets. In tabel 4 staan de rendementen voor de bicders over de gekozen periodes na de verwijdering van twaalf uitbijters.

Zoals blijkt zijn de T-waarden in geen van de tijdsperiodes significant bij een niveau kleiner dan tien procent. Een fusiebericht doet aandeelhouders van de bieders dus niet massaal besluiten om de aandelen te verkopen. Het rendement stijgt ook niet abnormaal door grote belangstelling van de markt voor aandelen van de bieder omdat men hogere cashflows verwacht na een fusic. Om een beter inzicht te verkrijgen in de verdeling van het CAR over de steckproef is deze in figuur 3 ook grafisch weergegeven voor de gehele onderzoeksperiode.

Tabel 5: Descriptives van het $\mathrm{C} A \mathrm{R}$ van de bieders

\begin{tabular}{|lll} 
& $C A \bar{R}$ & $\overline{C A R}$ \\
& kleiner dem mul & \multicolumn{1}{c}{ groter dan mul } \\
\hline Aantal & 43 & 46 \\
Minimum CAR & $-24.27 \%$ & $0.2 \%$ \\
Maximum CAR & $-0.78 \%$ & $35.93 \%$ \\
Gemiddeld & $-6.83 \%$ & $8.2 \%$ \\
Medianan & $-5.56 \%$ & $5.27 \%$ \\
\hline
\end{tabular}

Tabel 6: Overzicht onderzocksresultaten naar het CAR van de bieder

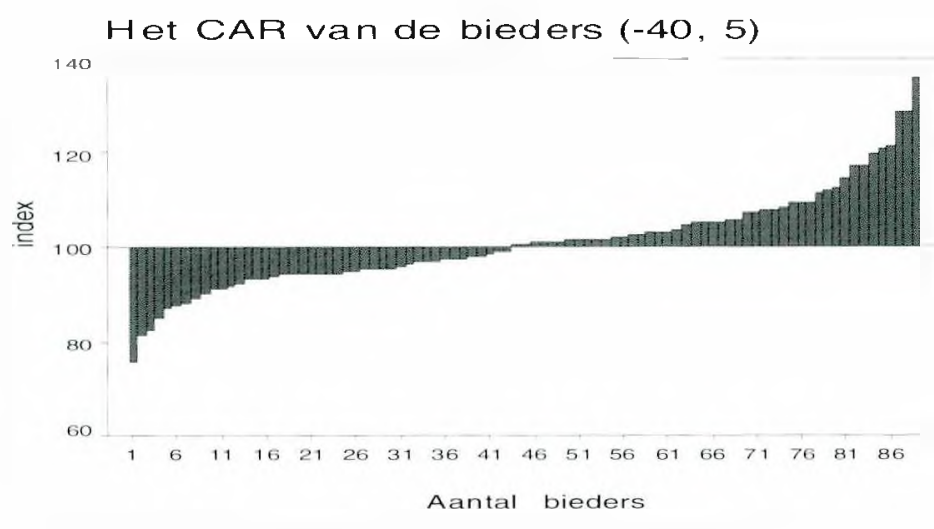

Figun 3: Distrihutic van her C.AR roor de hieders in de steekprosf

Uit tabel 5 blijkt dat bij $48 \%$ van de bieders het CAR negatief is in de onderzoeksperiode met een minimum van $-24,27 \%$ en een gemiddelde van $-6.83 \%$. Bij de $52 \%$ van de bieders die een positief rendement halen is het maximum $35,93 \%$ met een gemiddelde van $8,2 \%$. Aan de hand van deze tabel en het grafisch overzicht is het logisch te verklaren dat het gemiddelde $C A R$ van de bieders niet significant kan zijn, daar de gemiddelden elkalar sterk nivelleren. De resultaten van andere onderzockers naar het cumulatieve gemiddelde abnormale rendement van bieders rond de fusieperiode zijn te vinden in tabel 6 .

\subsubsection{Oreraich ran het tolale CAR}

Om de significantic van het gezamenlijke cumulatieve gewogen gemiddelde abnormale rendement (TCAR) te berekenen over de verschillende periodes is een eenzijdige T-toets uitgevoerd. De significantie is berekend met de eerder genoemde toetsgrootheid T. Bij de doelwitten waren hoge positieve rendementen te zien, maar bij de bieders was er geen sprake van een abnormaal rendement. Het is dus te verwachten dat het gezamenlijke CAR positief is.

\begin{tabular}{|c|c|c|c|c|c|}
\hline Ondersoek & $\begin{array}{l}\text { Steekproef } \\
\text { Periode }\end{array}$ & $\begin{array}{l}\text { Sreekproef } \\
\text { grootle }\end{array}$ & Land & Perionde & CAR bicale's \\
\hline $\begin{array}{l}\text { Van Frederikslusi. Van der Wal en } \\
\text { Westdijk (1999) }\end{array}$ & $1954-1997$ & 101 & NL & $(-1,0)$ & $.25 \%$ \\
\hline Bosveld. Mcyer en Vorst (1997) & $1970-1994$ & 122 & NL & $(-1.0)$ & $-.01 \%$ \\
\hline Sirower (1994) & $1979-1990$ & 168 & VS & $(-1,+1)$ & $-2.3 \%$ \\
\hline De Bruijn en Van Frederikslust ( 1994 ) & $1980-1993$ & 39 & NL & $(-1 .+1)$ & $-1.8 \%$ \\
\hline Morck. Schleifer en Vishny (1990) & $1980-1987$ & 172 & VS & $(-1 .+1)$ & $-1.78 \%$ \\
\hline Berkovitch en Narayanan (1993) & $1963-1988$ & 330 & VS & $(-5,+5)$ & $-.3 \%$ \\
\hline Franks en Harris (1989) & $1955-1985$ & 1048 & UK & $(-[.0)$ & $1 \%$ \\
\hline Bradley, Desai en Kim (1988) & $1981-1984$ & 52 & VS & $(-5,+5)$ & $-2.9 \%$ \\
\hline
\end{tabular}


Het Totale CAR $(-40,5)$

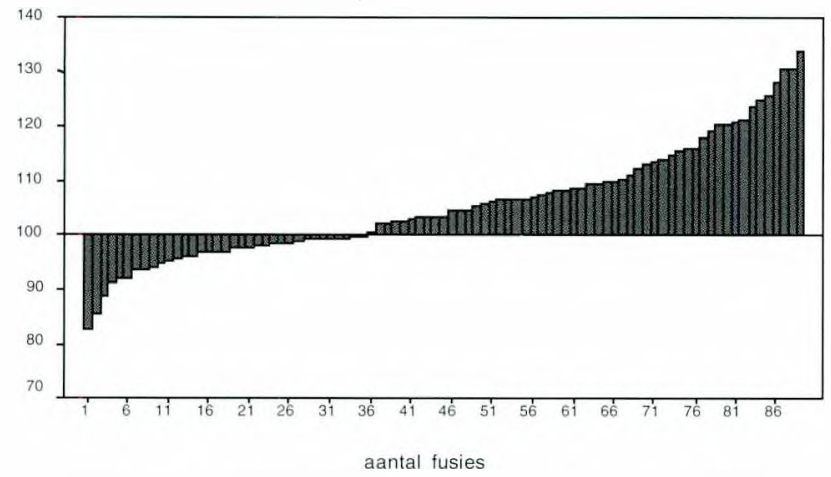

Figuur 4: Distributie van het totale CAR (TCAR) in de steekproef de periode $t(-1,5)$ ten opzichte van $t(-1,0)$. In de periode na de bekendmaking blijkt er een terugval te zijn van het TCAR. Om een grafisch overzicht van de verdeling te maken is het CAR per fusie van de bieder en het bijbehorend doelwit genomen. Op deze manier kan het aantal positief beoordeelde fusies worden weergegeven uit de steekproef.

In de onderzoeksperiode $(-40,5)$ is er bij $60 \%$ van de fusies sprake van een positief totaal rendement met een gemiddelde van 11,49\%. De overige $40 \%$ behaalt een negatief rendement van gemiddeld $4,08 \%$.

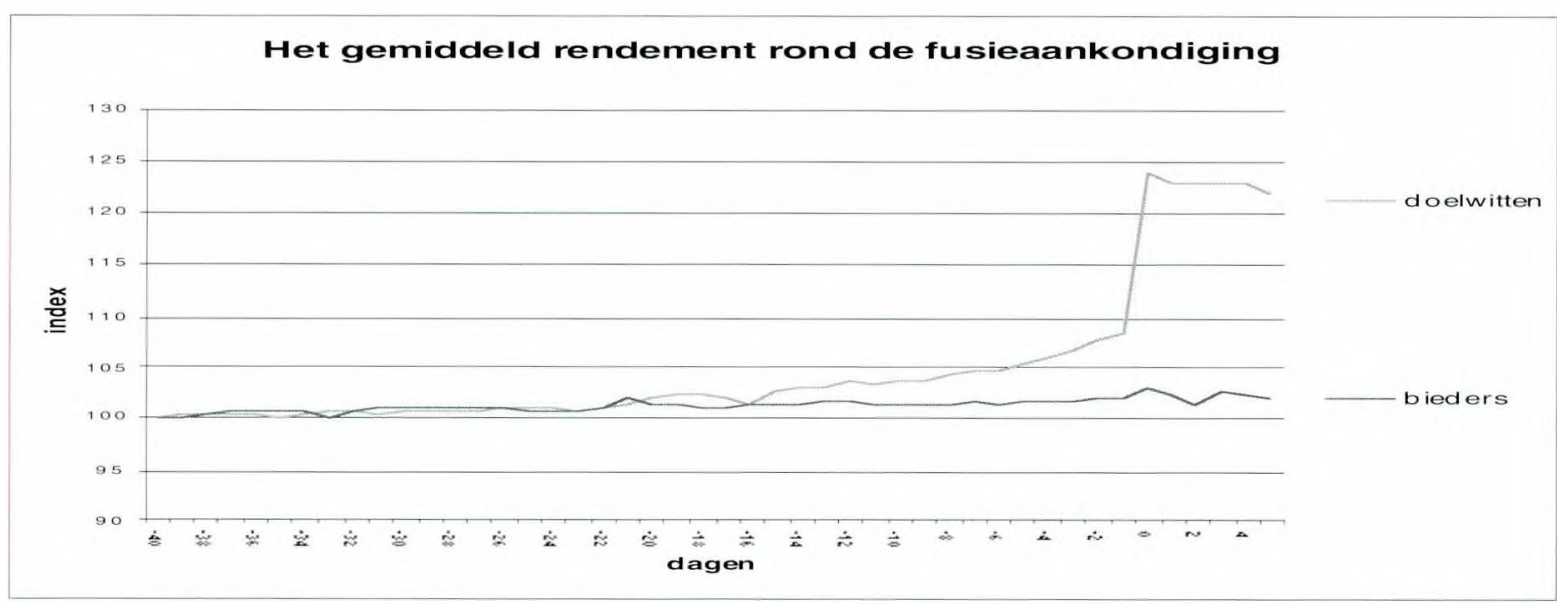

Figuur 5: Overzicht van het CAR van de bieders en de doelwitten vanaf dag -40 tot 5 dagen na het bod

In tabel 7 staan de totale rendementen voor de gekozen periodes na verwijdering van twaalf uitbijters.

Uit deze waarden blijkt dat het gezamenlijke CAR voor alle periodes significant is. Uit de resultaten komt duidelijk naar voren dat voor alle tijdsperiodes het cumulatieve gewogen gemiddelde abnormale rendement significant positief is. Opvallend is ook de teruggang van het TCAR in

Tabel 7: Het totaal rendement in de verschillende 1 ijdsperiodes

\begin{tabular}{|lll|}
\hline Tijdsperiode & CAR & T-waarde \\
\hline TCAR $(-1,0)$ & $2,73 \%$ & $4,047 * *$ \\
TCAR $(-1,+5)$ & $1.47 \%$ & $2.023 *$ \\
TCAR $(-10,+5)$ & $3,35 \%$ & $3,134 * *$ \\
TCAR $(-20,+5)$ & $3,99 \%$ & $3.279 * *$ \\
TCAR $(-40,+5)$ & $4,80 \%$ & $3,066 * *$ \\
\hline
\end{tabular}

** significant bij een niveau van 5 procent

* significant bij een niveau van 10 procent

\subsubsection{Grafisch overzicht van de ontwikkeling van het CAR}

Voordat de regressie wordt besproken volgt hier een grafisch overzicht van de gemiddelde rendementen van alle bieders en doelwitten uit de steekproef gedurende de gehele onderzoeksperiode. Uit figuur 5 is duidelijk op te maken dat het

Tabel 8: Descriptives van het totale CAR

\begin{tabular}{lll}
\hline & $\begin{array}{l}\text { TCAR } \\
\text { kleiner dan nul }\end{array}$ & $\begin{array}{l}\text { TCAR } \\
\text { groter dan nul }\end{array}$ \\
\hline Aantal & 36 & 53 \\
Minimum TCAR & $-17,63 \%$ & $0.44 \%$ \\
Maximum TCAR & $-0,11 \%$ & $34,05 \%$ \\
Gemiddeld & $-4.08 \%$ & $11.49 \%$ \\
Mediaan & $-3.05 \%$ & $8.57 \%$ \\
\hline
\end{tabular}

rendement van de doelwitten rond de fusieaankondiging explosief stijgt. Ook is te zien hoe vijftien dagen voor het bod openbaar is gemaakt het rendement voor de doelwitten al sterk toe- 


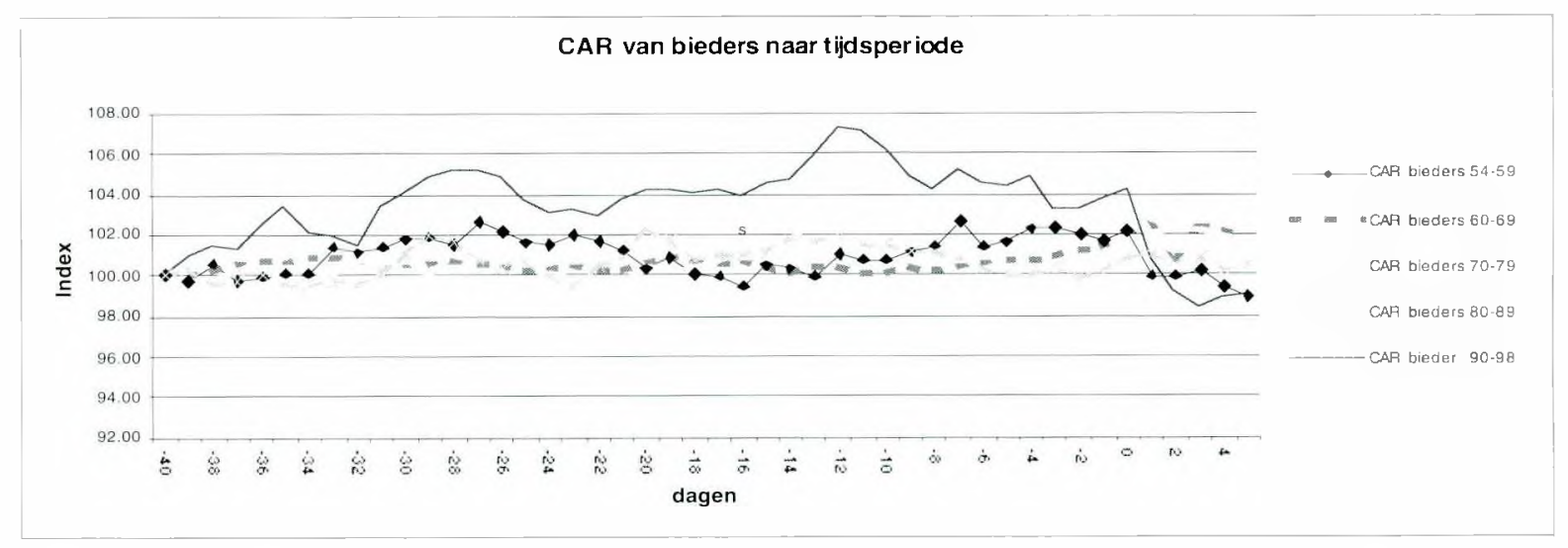

Figuul 6: Overzicht van het CAR van de bieders vanaf dag -40 tot 5 dagen na het bod naar tijdsperiode

neemt. Deze stijging kan veroorzaakt worden door de bieder die alvast aandelen probeert te kopen voordat het bod, dat veelal hoger is. wordt gedaan. Een oorzaak kan ook zijn dat personen die over voorkennis beschikken gaan beleggen in aandelen van een doelwit. Een dag na de fusieaankondiging is er in de grafiek e $\boldsymbol{n}$ lichte daling van de rendementen te zien.

Hierna zijn twee grafieken op: renomen met het CAR voor de bieder en dat va 1 het doelwit naar verschillende tijdsperiodes.

Uit figuur 6 is op te maken dat de koers van de bieder in alle periodes daalt op het moment van een fusicaankondiging. In de periode 1960- periode die zijn opgenomen in de steckproef.

De grafiek van de doelwitten (figuur 7) laat enkele opvallende zaken zien. In drie periodes daalt de koers een dag na het bod, terwijl in de periode 1970-1979 en 1980-1989 de kocrs ongewijzigd blijft. De sterkste terugval van de koers is te vinden in de periode 1990 tot 1998 Tevens is te zien dat de koersstijging voor het bod sterk afneemt in de periode na 1989. Deze lagere runup hangt wellicht samen met de versterkte controle op het handelen met voorkennis. In de regressie- analyse wordt het variabele fusiejaar opgenomen zodat mogelijke significante verschillen tussen het rendement in de tijdsperiodes aan het licht kunnen komen.

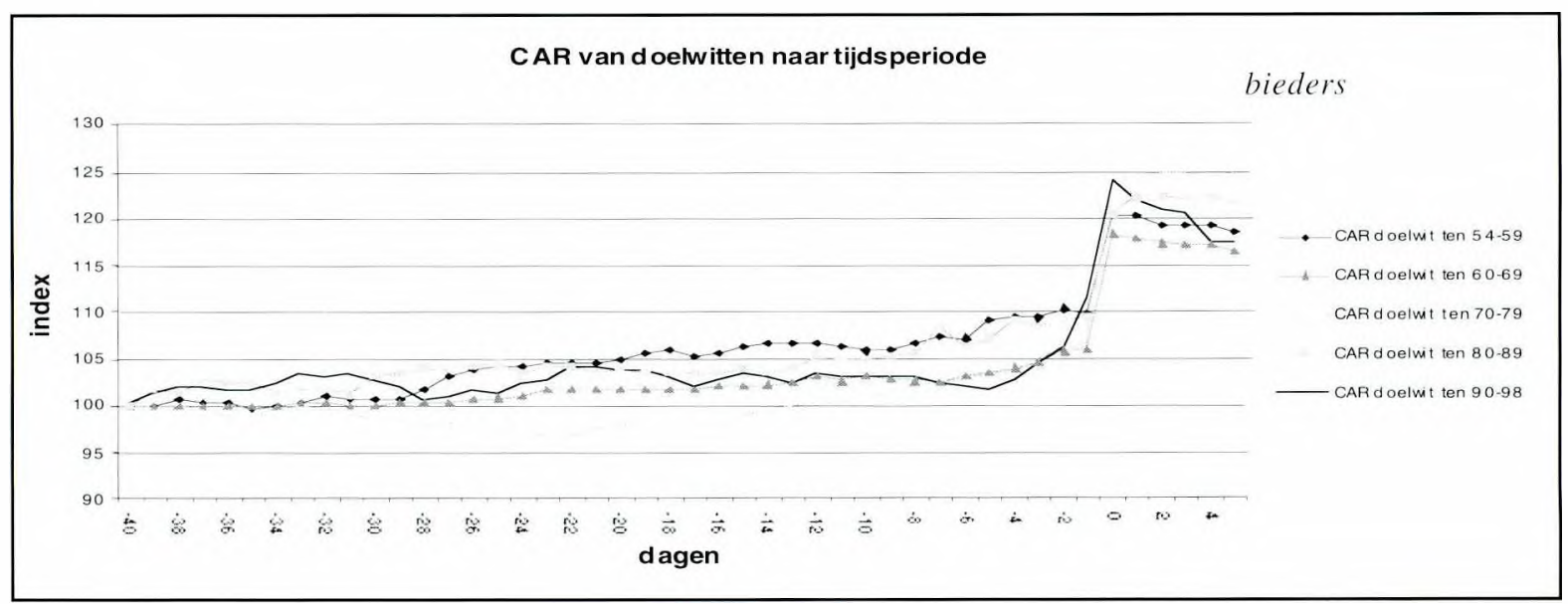

Figuur 7: Overzicht van het CAR van de doelwitten vanaf dag -40 tot 5 dagen na het bod naar tijdsperiode

1969 herstelt de koers van de bieder zich echter al drie dagen na de aankondiging. De lijn van de periode 1990 tot 1998 springt eruit, maar dit hangt vooral samen met het geringe aantal fusies uit deze

\subsection{Regressiemodellen}

Om een koppeling te maken tussen het cumulatieve gemiddelde abnormale rendement 
(CAR) van een fusic en de fusietheorieën zijn variabelen afgeleid die als indicator dienen voor de benoemde motieven. De bijdrage aan het CAR van deze indicators of proxies geeft een beeld van de moticren dic in Nederland ten grondslag liggen aan de managementbeslissing om tot een fusie over te gaan. Middels een regressieonderzoek wordt de bijdrage van deze proxies getoetst.

\section{Richting ran een fusie}

Horizontale fusies en overnames zullen gemiddeld een positieve reactie van het CAR laten zien door de duidelijk waarneembare mogelijkheden van sinergie. De verwachte meerwaarde komt uit management-en operationele verbeteringen (Eriksson, Högfeldt en Spens. 1998). De markttheorie (De Jong. 1998) benadert horizontale fusies als een proces dat ondernemingen aangaan om kosten te besparen en nieuwe markten te betreden om de ontstane overcapaciteit te benutten en de concurrentic te verlagen. Deze fusies worden aangegaan om strnergie te creëren. Uit empirisch onderzoek betreffende de Nederlandse situatie over de periode 1979- 1995 (Bosveld, Meyer en Vorst. 1997) blijkt dat door horizontale fusies het totale $C A R$ van bieder en doelwit positicf is.

Bij verticale fusies is sinergie niet waarschijnlijk. ondanks de lagere inkoopkosten (neerwaarts) of hogere marges (bovengericht). door het gebrek aan schaalvoordelen en de problemen die de integratic van twee verschillende ondernemingen met zich meebrengt (Morck "' al. 1990). Deze fusies laten dus een negatieve totale CAR zien.

Het motief bij diagonale fusies is meestal het streven naar diversificatic. Door op verschillende markten aanwezig te zijn wordt het risico voor de onderneming gespreid. Diagonale fusies zullen gemiddeld een negatieve koersreactie laten zien omdat andeelhouders zelf al diversificeren en menen dat de kosten van een ovemame niet zijn terug te verdienen. Diagonale fusies dienen niet het doel van de aandeelhouder. maar dat van het management van een onderneming. Het agencymotief speelt bij dit soort fusies een duidelijke rol. Uit empirisch onderzoek blijken deze fusies en overnames het slechts scoren omdat mogelijke slnergie vrijwel niet te behalen is (Morck et al..1990).

In ons onderzoek is het weinig zinvol het effect van de richting van de fusies en acquisities te meten daar 93\% van de fusies en acquisities horizontaal van richting waren en slechts $7 \%$ verticaal. Wel wordt op grond van de markttheorie van De Jong (1998) verwacht dat horizontale fusies en acquisities door de krachtenbundelingen van ondernemingen in vergelijkbare sectoren eerder synergie zullen opleveren dan verticale en diagonale fusies en acquisities.

\section{Mathode van betaling}

Het bod op de aandelen van het doelwit kan zijn in effecten. contanten of in cen gemengde vorm van beide betalingsmethoden. Over de inv loed van de betalingsmethode op het verwachte rendement bestaat geen eenduidige mening in de literatuur. Het voordecl van de betaling in effecten is dat er door middel van uitgifte van nieuwe aandelen eigen vermogen wordt geschapen, waarmee de betaling voldaan kan worden. De liquiditeitspositic komt hierbij niet in geviar. De kans op een te hoge overnamepremic zal gering zịn bij de betaling in effecten ondat do aandeclhouders van het doelwit ook risico lopen bij een te hoge prijs. Dit is de contingent pricing effect of stockponment-hypothese (Hansen. 1987). die onzes inziens voorbijgat aan de mogelijkheid van aandeelhouders om hun aandelen direct na inwisseling te verkopen. wanneer zij menen dat de aandelen van de overnemende partij zijn overgewaardeerd.

Tegenstanders van de betaling in effecten menen dat door de betaling van een overname met eigen vermogen er een signaal wordt afgegeven. Deze signaling effects of stock issues houden in dat betaling in effecten een negatief signaal is ondat door de informatieasymmetrie, bieders alleen de voorkeur hebben voor betaling in effecten wanneer zij denken dat deze door de markt zijn overgewaardeerd. terwijl de werkelijke waarde van geld snel is vast te stellen (Myers en Maljuf, 1984, Berkovitch en Narayanan, 1990). Men houdt tevens geen rekening met de verwatering van de totale uitstaande aandelen, zodat de werkelijke kosten veel hoger uitvallen. Managers kunnen door deze vorm van betaling in de toekomst niet direct afgerekend worden op hun investeringsbeslissingen en het streven naar synergie wordt door deze agenci-problemen minder noodzakelijk. De beurs erkent deze problematiek en zal door he verlies van controlemogelijkheden en de verwatering van de aandelen 
overgaan tot verkoop van de andelen van de bieder, met als resultaat een daling van de aandelenkoers op het moment van bekendmaking van het bod.

Over het algemeen wordt verwacht dat de betaling in contanten een positieve invloed heeft ondat dit onathankelijk is van enige informaticasymmetrie. De prijs van een overname is geheel duidelijk en wordt over het algemeen gefinancierd met vreend vermogen zodat men genoodzaakt is om een rendement te behalen dat voldoende is om de schuldenlast te voldoen. De gemaakte kosten van vreemd vermogen zijn in tegenstelling tot dat van eigen vermogen in de jaarrekening terug te vinden, zodat de managers afgerekend kunnen worden op hun beslissingen. De aflossingen en renteverplichtingen zullen de managers aansporen om snel synergie te realiseren (Sirower, 1997).

\section{Marktklimaat}

Bepaalde tijdsperiodes kemmerken zich door grote concurrentic op de overnamemarkt. Er zijn in de onderzoeksperiode drie fusiegolven te herkennen die vanuit de Verenigde Staten overwaaiden, namelijk de derde golf van 1966-1973, de vierde golf 1984-1989) (Van Duijn. 1992) en de vijlde fusiegolf die nu nog gaande is. Deze industriële fusiegolven ontstaan door en reactie van ondernemingen op een veranderende markt. Deze factoren verschillen per bedrijfstak: de texticlindustrie in Nederland bijvoorbeeld werd in de jaren 60 bedreigd door gocdkope import en moest om schaalvoordelen te behalen de kostprijs verlagen. In dezelfde periode moesten de vele machinefabrieken investeren in dure moderne productielijnen om de concurrentie met Europa aan te kunnen gaan. Op het moment dat een concurrent zijn marktpositic dreigt te verbeteren door een fusie, volgen de anderen met een zelfde strategic. Een fusie is in deze omstandigheden niet alleen strategisch goed te verdedigen door managers, maar is ook de snelste manier om de problemen het hoofd te bieden. doordat financiële en productieve schaalvoordelen sncl te behalen lijken (Mitchell en Mulherin. 1996).

Nadat de eerste fusic heeft plaatsgevonden gaan de koersen van overnamekandidaten stijgen. De koers van de doelwitten stijgt door speculaties van aandechouders door te beleggen in potentiële doelwitten of door de beschermingsconstructies van ondernemingen die een overname bemoeilij$\mathrm{ken}$. De controlepremie die betaald moet worden om cen fusic te bewerkstelligen zal de tockomstige simergie al snel overtreffen. De kans dat er te veel wordt betaald om tot een fusie te komen is derhalve groot. De koers van de bieder wordt negatief beïnvloedt bij een overnamebericht, omdat de markt geen sinergie verwacht (Morck et al.. 1990). Deze denkwijze komt overeen met de speltheorie, wararbij men fusiegolven verklaart door de mate van afkeur van managers om risico te lopen en zich te laten leiden door de markttendens.

\section{Koersonwikkeling vorafgand an het hod}

Als analyseperiode is een jaar genomen voor de bekendmaking van het openbaar bod. Deze koersontwikkeling wordt op maandbasis vastgesteld. De ontwikkeling van de koers geeft het vertrouwen van de markt in de onderneming en haar toekomst aan. Ondernemingen met een stijgende koers van de aandelen blijken interessante doelwitten (Eriksson. Högfeldt en Spens. 1998) voor de aandeelhouders van de bieder. Deze ondernemingen hebben in het verleden een goede reputatic opgebouwd op de markt. Een onderneming met stijgende koersen zal hierdoor eerder gezien worden als een waardevolle anvulling door de aandeclhouders van de bieder. Deze stijging dient vrij te zijn van invloeden als beschermingsconstructies en speculaties. Uit eerder empirisch onderzoek blijken de ondernemingen met stijgende koersen de slechtste bieders. Dit komt overeen met de hubristheorie waarbij managers van goedlopende ondernemingen zichzelf overschatten en zich zo mindere acquisities kunnen permitteren (Bosveld. Meyer en Vorst, 1997). Het gezamenlijk CAR zal na bekendmaking van het openbaar bod van de bieder waarschijnlijk een daling laten zien.

Bij de overname van een onderneming met een stijgende beurskoers zal hubris een kleinere rol spelen, daar het risico minder groot is. Toch zal de fusie door de andeelhouders minder gewaardeerd worden, daar men zelf goedkoper kan diversificeren door middel van de aanschaf van aandelen in beide ondernemingen. Deze reactic kan worden opgevat als een agencyprobleem. maar zal wanneer het grocipotentieel en het vertrouwen van de markt in beide ondernemingen groot zijn, middels het CAR na het bod niet snel herkenbaar worden. 
Ondernemingen met dalende koerscijfers zullen alleen tot een fusic overgaan wanneer er duidelijk watrneembare şnergie mogelijk is. De onderneming en haar management verdienen niet genoeg vertrouwen op de markt en kan zich geen misser veroorloven door de scherpe controle van de alandeelhouders. Tevens zal een onderneming met dalende koerscijfers niet snel een fusie financieren door middel van een aandelenemissie. Een verwatering van de alandelen en het gebrek aan controlemogelijkheden signaling effects of stock issures) zal niet geaccepteerd worden en zal de koers nog meer doen dalen. Een bedrijf met dalende koerscijfers zal naar verwachting een positief CAR laten zien na bekendmaking van het openbalar bod.

\section{Controle variahelen}

llet doel van het onderzock is het verklaren van het rendement van fusies an de hand van verschillende variabelen, waarbij getracht wordt cen koppeling te maken naar de heersende theorieën. Niet alle variabelen zijn echter te plaatsen in dit theoretisch kader doch dienen voor de volledigheid wel meegenomen te worden in het regressiemodel omdat deze invloed kunnen hebben op het CAR.

Ilet eigen rermogen ran de bieder kan als indicator gebruikt worden voor de kwaliteit van haar management. Een grote onderneming zal meer managementskwaliteiten en -ervaring bezitten dan een kleine onderneming, waardoor de fusie vermoedelijk beter doordacht en voorbereid zal zijn. Omdat dit onderzoek over cen periode van meer dan 40 jaar gal wordt het eigen vermogen zoveel mogelijk gecorrigeerd voor inflaticl. De relatieve omvang van een orername zal mogelijk insloed hebben op het CAR van de fusicpartners. Deze relatieve omvang wordt berekend als het eigen vermogen van de bieder gedeeld door dat van het doelwit. Als tijdstip van deze berekening wordt 40 dagen vóór bekendmaking van het bod gebruikt. Het is vanzelfsprekend dat wanneer dit verhoudingscijfer stijgt, het rendement van de bieder minder wordt beünvloed door een fusicbericht. Op het rendement van het doelwit kan het een negaticve invloed hebben doordat een grote onderneming meer onderhandelingsmacht en -ervaring heeft. Hicrdoor zal het bod laag blijven ondat men de sinergie-voordelen al heeft vastgesteld. Als symergie-motieven niet meespelen zal de kans op een hoog rende- ment voor het doelwit toenemen omdat een kleine overname voor de biedende managers weinig risico mecbrengt, ondanks dat de werkelijke waarde van de overname minder blijkt te zijn dan men ervoor betaalde. Waarschijnlijk zal de variabele relatieve omvang weinig invloed hebben op het CAR in dit onderzock ondat alle ondernemingen beursgenoteerd waren en over een zekere onderhandelingsmacht en controle beschikken. De variabele hedriffstak is tevens ingevoerd. Wanneer blijkt dat voor een bepaalde industrietak de resultaten sterk afwijken van die van de overige bedrijfstakken zal hiernaar een apart onderzoek gedaan worden. De opgenomen bedrijtstakken zijn: industrie, handel en overige. Het fusiejaar zal opgenomen worden als variabele zodat mogelijke versehillen in rendementen uit hel verleden kunnen worden vergeleken. Wanneer er significante verschillen tussen de tijdsperiodes aan het licht komen kan hiervan een analyse plaatsvinden.

\section{Samenvatting in tahelvorm}

In tabel 9 en tabel 10 (zic pagina 276) staan de verwachtingen die behandeld zijn. waarbij naast de verklarende variabelen ook het verwachte effect op het fusierendement is opgenomen.

\subsection{Geschatte fincties en toetsingsiesultaten}

In de regressieanalyse zullen de cumulatieve (abnormale) rendementen dic behaald zijn bij de fusies en acquisities worden geanalyseerd door middel van de gekozen onafluankelijke variabelen. Van de onafhankelijke variabelen zullen er in de analyse elf worden opgenomen ter verklaring van het CAR van het doelwit. Bij de verklaring van de rendementen van de bieder worden er twaalf onathankelijke variabelen opgenomen. Bij de bicder wordt ook de variabele premie opgenomen. De premie is de hoogte van het overnamebod en deze kan niet bij twee de andere regressies worden opgenomen daar deze al opgenomen is in de koers van het doelwit; een (hoge) verklaring zou dan zeer vertekend zijn. Bij de regressic van het totale rendement wordt de variabele eigen vermogen van de bieder en het doelwit opgenomen. Voor een betere toepasbaarheid is gekozen om de natuurlijke logaritme te nemen van het voor inflatie gecorrigeerde eigen vermogen. Voor de bieder wordt opgenomen lncorerb en voor het doelwit Incorreved. 
label 9: Waarecreërende theorieën

\begin{tabular}{|c|c|c|c|}
\hline & & & \\
\hline Variabelen & Allewis & Proxie & $\begin{array}{l}\text { Veru: Imvoed op } \\
C A R\end{array}$ \\
\hline Richting van de fusie & $\begin{array}{l}\text { Eriksson. Högteldt, Spens. Bosveld. } \\
\text { Meyer en Vorst. De Jong. }\end{array}$ & Horizontaal & + \\
\hline Methode van betaling & $\begin{array}{l}\text { Sirower. Meyers. Maljuf, } \\
\text { Berkovitch. Narayanan en Fishman }\end{array}$ & Contant & + \\
\hline Marktklimaat & $\begin{array}{l}\text { Morck. Schleifer. Vishny. Mitchel } \\
\text { en Mulherin }\end{array}$ & Geen fusiegoli & + \\
\hline $\begin{array}{l}\text { Koersontwikkeling voor } \\
\text { bod }\end{array}$ & Bosveld. Meyer en Vorst & $\begin{array}{l}\text { Dillende koers } \\
\text { hieder }\end{array}$ & + \\
\hline
\end{tabular}

Tabel 10: Herverdelingtheorieën

\begin{tabular}{|c|c|c|c|c|}
\hline lariabelen & Allewrs & Provie & Theorie & $\begin{array}{l}\text { Verw: Invloed op } \\
\text { CAR }\end{array}$ \\
\hline Richting van de fusie & $\begin{array}{l}\text { Eriksson, } \\
\text { Högfeldt, Spens. } \\
\text { Bosveld, Meyer } \\
\text { en Vorst }\end{array}$ & Verlical & $\begin{array}{l}\text { Agency / } \\
\text { Hubris }\end{array}$ & - \\
\hline Methode van betaling & $\begin{array}{l}\text { Sirower, } \\
\text { Fishman }\end{array}$ & $\begin{array}{l}\text { Aandelen } \\
\text { Gemengd }\end{array}$ & Agency & + \\
\hline Masktklimaat & $\begin{array}{l}\text { Morck, Schleifer. } \\
\text { Vishny, Mitchel } \\
\text { en Mulherin. } \\
\text { Schenk }\end{array}$ & Fusievolgers & $\begin{array}{l}\text { Agency / } \\
\text { Spel }\end{array}$ & - \\
\hline $\begin{array}{l}\text { Koersontwikkeling voor } \\
\text { bod }\end{array}$ & $\begin{array}{l}\text { Bosveld, Meyer } \\
\text { en Vorst }\end{array}$ & $\begin{array}{l}\text { Stijging bieder en } \\
\text { daling doelwit } \\
\text { Stijging bieder en } \\
\text { doelwit }\end{array}$ & $\begin{array}{l}\text { Hubris } \\
\text { Agency }\end{array}$ & - \\
\hline
\end{tabular}

Daar horizontale fusies $93 \%$ uitmaken van het geheel is het weinig zinvol het effect van de richting van de fusics en acquisities op het CAR te schatten en is deze variabele niet opgenomen in de regressicanalyse.

De gecreëerde dichotome variabelen kunnen niet allemaal worden opgenomen omdat de onderlinge logische samenhang zou kunnen leiden tot multicollineariteit. Voor de betalingsmethode zijn aandelen en contant opgenomen. Voor de analyse van de invloed van het marktklimat is opgenomen: fusiegolf. De invloed van bedrijfstak wordt bepaald met de variabelen: handel en industrie.

De ratio variabelen dic worden opgenomen zijn: het jaar van de fusie, verhouding cigen vermogen, de natuurlijke logaritme van het gecorrigeerde eigen vermogen, de koers van de bieder voor bod en de koers van het doelwit voor bod. Bij de regressieanalyse van de bieder is de variabele premic opgenomen.

\subsubsection{Regressieresultaten roor het doehwit}

Uit tabel 11 blijkt dat twee variabelen significant verklarend zijn voor het CAR van de doclwitten. De verhouding van het eigen vermogen ( $E v$ bieder/Ev doelwit) is voor alle periodes significant op een niveau van vijf procent. Een grote verhouding van het eigen vermogen leidt tot significant hogere rendementen voor de doelwitten. Tevens is de variabele betaling in aandelen significant in drie periodes. De betaling in aandelen doet het CAR voor het doelwit zoals verwacht, dalen. De overige variabelen zijn niet significant, mar geven wel een indicatie voor de richting van hun invloed. De variabelen koers van bieder voor het bod en de koers van doelwit voor het bod hebben te loge standaardfouten in bijna alle periodes van de regressie en hebben dus geen invloed op het rendement van het doelwit. Gezien de F-waarden zijn alle geschatte functie significant, op cen niveau van vijf of tien procent. 
Opgenomen in de analyse zijn 88 doelwitten. Het regressiemodel voor het CAR van de doelwitten heeft de onderstaande vorm.

$$
\begin{aligned}
\operatorname{CAR}\left(t_{1}, t,\right)= & \alpha+\beta_{1} \text { Incorrel }+\beta_{2} \text { lerhev }+\beta_{3} \text { cont }+\beta_{+} \text {atand }+\beta_{5} \text { fusiegolf }+\beta_{6} \text { hand }+\beta_{7} \text { indus }+ \\
& \beta_{8} \text { doevobo }+\beta_{9} \text { bievobo }+\beta_{10} \text { fusiejr }+\varepsilon \quad \varepsilon \sim(0, \sigma)
\end{aligned}
$$

$C A R\left(t, t_{1}\right)$ staat voor het cumulatieve gemiddelde abnormale rendement in een tijdswindow beginnend bij $t$ tot $t$ en is de athankelijke variabele in het model. De constante in het model is $\alpha$ en de onafhankelijke variabelen worden vermenigvuldigd met de $\beta$. Lncorrev is de naturlijke logaritme van het voor inflatie gecorrigecrde eigen vermogen. Verher is het eigen vermogen van de bieder gedeeld door dat van het doelwit. Comam en aandelen zijn dummyvariabelen voor de methode van betaling. Fusiegolf is een dummy ariabele die weergeeft of er in ecn periode sprake was van een fusiegolf. Handel en industrie zijn dummyvariabelen voor de sector. Doevoho en bievobo geven de kocrsontwikkeling van het doelwit en de bieder weer in de tijdsperiode van één jaar vóór de fusie. De tijdsperiode loopt van 100 dagen tot 41 dagen vór het openbaar bod. Het fisiejr is het jaartal van een lusie verminderd met 1900. De zinvolheid van de geschatte functic is getoetst door middel van een F-toets. De verklarende variabelen zijn getoetst op multicollineariteit middels de VIF-loets en zijn alle in het model opgenomen. In de tabel staan tussen haakjes de bijbehorende standaardfouten van de

\begin{tabular}{|c|c|c|c|c|c|}
\hline Variabele & CAR $(-1,0)$ & $C A R(-1,5)$ & CAR $(-10,5)$ & $C A R(-20,5)$ & CAR $(-40,5)$ \\
\hline Constante & $\begin{array}{l}106.395 * * \\
(11.570)\end{array}$ & $\begin{array}{l}108.867 * * \\
(12.867)\end{array}$ & $\begin{array}{c}98.537 \text { *** } \\
(16.828)\end{array}$ & $\begin{array}{l}102.014 * * \\
(18.992)\end{array}$ & $\begin{array}{l}95.466^{* *} \\
(19.480)\end{array}$ \\
\hline Lncorrev & $\begin{array}{l}1.048 \\
(1.371)\end{array}$ & $\begin{array}{l}1.542 \\
(1.525)\end{array}$ & $\begin{array}{l}3.414 * \\
(1.994)\end{array}$ & $\begin{array}{l}3.438 \\
(2.251)\end{array}$ & $\begin{array}{l}3.711 \\
(2.309)\end{array}$ \\
\hline Verhev & $\begin{array}{l}.685^{* *} \\
(.297)\end{array}$ & $\begin{array}{l}.769 * * * \\
(.330)\end{array}$ & $\begin{array}{l}1.077^{*} * \\
(.431)\end{array}$ & $\begin{array}{l}1.195^{*} * \\
(.487)\end{array}$ & $\begin{array}{l}1.511 \text { 沵 } \\
(.499)\end{array}$ \\
\hline Contant & $\begin{array}{l}-.577 \\
(3.670)\end{array}$ & $\begin{array}{l}.771 \\
(4.081)\end{array}$ & $\begin{array}{l}4.586 \\
(5.337)\end{array}$ & $\begin{array}{l}4.476 \\
(6.024)\end{array}$ & $\begin{array}{l}4.346 \\
(6.178)\end{array}$ \\
\hline Acund & $\begin{array}{l}-9.461 * * \\
(3.101)\end{array}$ & $\begin{array}{l}-11.268 * * \\
(3.449)\end{array}$ & $\begin{array}{l}-6.831 \\
(4.5 ! 1)\end{array}$ & $\begin{array}{l}-9.699 \% \\
(5.091)\end{array}$ & $\begin{array}{l}-8.356 \\
(5.221)\end{array}$ \\
\hline Fusiegolf & $\begin{array}{l}-.677 \\
(2.691)\end{array}$ & $\begin{array}{l}.161 \\
(2.993)\end{array}$ & $\begin{array}{l}.932 \\
(3.914)\end{array}$ & $\begin{array}{l}3.316 \\
(4.417)\end{array}$ & $\begin{array}{l}1.480 \\
(4.531)\end{array}$ \\
\hline Hand & $\begin{array}{l}1.973 \\
(4.659)\end{array}$ & $\begin{array}{l}2.469 \\
(5.181)\end{array}$ & $\begin{array}{l}5.339 \\
(6.775)\end{array}$ & $\begin{array}{l}3.103 \\
(7.647)\end{array}$ & $\begin{array}{l}10.333 \\
(7.843)\end{array}$ \\
\hline Indus: & $\begin{array}{l}-1.280 \\
(3.561)\end{array}$ & $\begin{array}{l}-1.090 \\
(3.910)\end{array}$ & $\begin{array}{l}.570 \\
(5.113)\end{array}$ & $\begin{array}{l}-.002 \\
(5.771)\end{array}$ & $\begin{array}{l}1.668 \\
(5.919)\end{array}$ \\
\hline Doevobo & $\begin{array}{l}-.037 \\
(.171)\end{array}$ & $\begin{array}{l}.095 \\
(.190)\end{array}$ & $\begin{array}{l}.111 \\
(.249)\end{array}$ & $\begin{array}{l}.035 \\
(.281)\end{array}$ & $\begin{array}{l}-.029 \\
(.288)\end{array}$ \\
\hline Bievobo & $\begin{array}{l}-.038 \\
(.155)\end{array}$ & $\begin{array}{l}-.057 \\
(.173)\end{array}$ & $\begin{array}{l}-.001 \\
(.226)\end{array}$ & $\begin{array}{l}.070 \\
(.255)\end{array}$ & $\begin{array}{l}-.157 \\
(.261)\end{array}$ \\
\hline Fusiejr & $\begin{array}{l}.075 \\
(.144)\end{array}$ & $\begin{array}{l}.004 \\
(.160)\end{array}$ & $\begin{array}{l}.086 \\
(.209)\end{array}$ & $\begin{array}{l}.076 \\
(.236)\end{array}$ & $\begin{array}{l}.165 \\
(.242)\end{array}$ \\
\hline$R^{2}$ & .229 & .251 & .176 & .188 & .233 \\
\hline $\mathrm{F}$ & $2.312^{* * *}$ & $2.620 * *$ & $1.67 I *$ & $1.801 *$ & $2.365 * *$ \\
\hline
\end{tabular}
geschatte regressiecoëfficiënten. 


\subsubsection{Regressieresultaten voor de bieder}

Uit tabel 12 (zie hieronder en op pagina 279) is te zien dat Lncorrev voor twee periodes significante waarden heeft, maar alleen in de periode ($1,0)$ is de standaardfout acceptabel. De betaling in contanten levert inderdaad zoals verwacht voor drie periodes een signifïcante positieve bijdrage. Betaling in contanten levert hogere rendementen op voor de bieder dan andere betalingsvormen. De variabele fusiegolf is ook in drie periodes significant. Een fusiegolf levert lagere rendementen op voor de bieder. Dit komt overeen met wat in de speltheorie wordt gesuggereerd. In twee periodes laat het jaar van de fusie een significante positieve invloed zien op het CAR. Blijkens de Ftoets zijn vier van de vijf geschatte modellen significant op een niveau van 5 of 10 procent.

\subsubsection{Regressieresultaten vor het totaal}

We hebben soortgelijke regressies ook geschat voor de gevormde combinaties op basis van het totale cumulatieve abnormale rendement TCAR. Daaruit is gebleken dat de variabelen Incorrevd en lncorer $h$ beide significant zijn in de periode

$(-10,5)$. Het gecorrigeerde eigen vermogen van het doelwit heeft een positieve invloed op het TCAR, terwijl dit van de bieder een negatieve bijdrage levert aan het TCAR. De verklaring voor deze samenhang zit deels in het feit dat de CAR van de doelwitten groot en positief zijn terwijl de CAR van de bieders laag en negatief zijn in de beschouwde periode. De betaling in aandelen is voor de periodes $(-1,0)$ en $(-1,5)$ significant en beïnvloedt het rendement negatief. De betaling in contanten levert een significante positicve bijdrage op voor de periode $(-20,5)$. De geschatte functies zijn op één periode $(-40.5)$ na significant op het 5 of 10 procentniveau.

\subsection{Biedingstrategie}

De pre-bid premic is de kocrsstijging die zich voordoet bij het doelwit voordat een openbaar bod is uitgebracht. Deze koersreactie wordt door verschillende factoren veroorzaakt. Vaak is dit een intentieverklaring van een bieder tot cen fusie of overname, maar dit kan bijvoorbeeld ook worden veroorzaakt door uitspraken van analisten over de te verwachten strategickoers van een onderneming of wanneer er gehandeld wordt met voorkennis. Er zijn twee hypotheses (Schwert, 1994) die de invloed van pre-bid premies verklaren in een situatic waarbij alleen de bieder en/of het doelwit nog op de hoogte zijn van een toekomstige fusie of acquisitic.

Bij de substitutie hrpothese wijkt de bieder niet meer af van de premic die men van tevoren heeft vastgesteld voor een overname. De onderhandelingspartners gaan ervan uit dat zij meer relevante informatie bezitten dan de markt. ledere pre-bid koersstijging voor het officiële bod wordt gecompenseerd door een lagere markup zodat de totale premie die wordt betaald gelijk blijft. De

\section{Tabel 12: De regressieresultaten voor de bieders}

Bij het regressiemodel van de bieder is de extra variabele premie opgenomen met 88 biedende ondernemingen voor vijf tijdsperiodes. Het regressiemodel voor de bieder ziet er als volgt uit:

$$
\begin{aligned}
\text { CaR }\left(t_{1}, h_{2}\right)= & \alpha+\beta_{1} \text { lncorrev }+\beta_{2} \text { verhev }+\beta_{3} \text { cont }+\beta_{4} \text { aand }+\beta_{5} \text { fusiegolf }+\beta_{6} \text { handel }+ \\
& \beta-\text { indas }+\beta_{5} \text { doevobo }+\beta_{4} \text { bievobo }+\beta_{10} \text { fusiejr }+\beta_{11} \text { premie }+\varepsilon \varepsilon-(0 . \sigma)
\end{aligned}
$$

$C A R(t, t)$ staat voor het cumulatieve gemiddelde abnomale rendement in een tijdswindow van $t$ tot $t$, De constante in het model is $\alpha$ en de onafhankelijke variabelen worden vermenigvuldigd met de $\beta$. Lncorrev is de naturulijke logarilme van het voor inflatic gecorrigeerde eigen vermogen. lerher is het eigen vermogen van do bieder gedeeld door dat van het doelwit. Contanl an atmolelen zijn dummyvariabelen voor de methode van betaling. Fusiegolf is een dummyvariabele die weergeefi of er in een periode sprake was van een fusicgolf. Handel en industrie zijn dummyariabelen voor de sector. Doevobo en bievobo geven de koersontwikkeling van het doelwit en de bieder weer in een tijdsperiode vór de lusie. De tijdsperiode loopt van 100 dagen tot 41 dagen vóm het openbar bod. Het firsicjp is hel jartal van cen fusie verminderd met 1900 . De variabele premie is de hoogte van hel geslaagde bod. De zinvolheid van de geschatte functic is getoetst middels een F-toets. De verklarende variabelen zijn getoetst op multicollineariteit door middel van de VIF-toets en zijn alle opgenomen in het model. In de tabel staan tussen hakjes de bijbchorende standaardfouten van de geschatle regressiecoëfficiënten. 


\begin{tabular}{|c|c|c|c|c|c|}
\hline Variabele & CAR $(-1,0)$ & $C A R(-1.5)$ & CAR(-10,5) & $C A R(-20.5)$ & $C A R(-40.5)$ \\
\hline \multirow[t]{2}{*}{ Constante } & $95.968 * * *$ & $100.682 * *$ & $104.602^{* * *}$ & $97.934 * *$ & $88.195 * *$ \\
\hline & $(3.783)$ & $(8.804)$ & $(11.139)$ & $(14.377)$ & $(18.6+9)$ \\
\hline \multirow[t]{2}{*}{ Lncorrer } & $-.489 * *$ & $-.854^{*}$ & -.970 & -1.351 & -1.703 \\
\hline & $(.215)$ & $(.500)$ & $(.632)$ & $(.816)$ & $(1.059)$ \\
\hline \multirow[t]{2}{*}{ Verher } & .036 & $.206 \%$ & .041 & .199 & -.003 \\
\hline & $(.049)$ & $(.115)$ & $(.145)$ & $(.188)$ & $(.244)$ \\
\hline \multirow{2}{*}{ Contant } & -.404 & $2.841 * *$ & 4.057 *** & $5.359 * *$ & 4.753 \\
\hline & $(.610)$ & $(1.419)$ & $(1.795)$ & $(2.317)$ & $(3,005)$ \\
\hline \multirow[t]{2}{*}{ Aand } & .169 & .217 & 1.031 & 1.109 & 3.496 \\
\hline & $(.542)$ & $(1.260)$ & $(1.595)$ & $(2.058)$ & $(2.670)$ \\
\hline \multirow[t]{2}{*}{ Fusiegolf } & $-.958 * *$ & -.989 & -1.753 & $-2.587 *$ & $-4.017 *$ \\
\hline & $(.448)$ & $(1.042)$ & $(1.319)$ & $(1.702)$ & $(2.208)$ \\
\hline \multirow[t]{2}{*}{ Hand } & .728 & $3.341 *$ & 1.581 & 1.139 & 4.315 \\
\hline & $(.780)$ & $(1.816)$ & (2.297) & $(2.965)$ & $(3.846)$ \\
\hline \multirow[t]{2}{*}{ Induss } & .332 & -.013 & .895 & 1.796 & 1.603 \\
\hline & $(.586)$ & $(1.364)$ & $(1.726)$ & $(2.227)$ & $(2.889)$ \\
\hline \multirow[t]{2}{*}{ Doevobo } & -.005 & .033 &.$-(022$ & .128 & .104 \\
\hline & $(.029)$ & $(.068)$ & $(.086)$ & $(.111)$ & $(.144)$ \\
\hline \multirow[t]{2}{*}{ Bievobo } & .029 & -.054 & -.020 & -.152 & -.122 \\
\hline & $(.026)$ & $(.059)$ & (.075) & $(.097)$ & $(.126)$ \\
\hline \multirow[t]{2}{*}{ Fusiejr } & 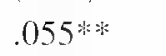 & .039 & .014 & .086 & $.224 *$ \\
\hline & $(.024)$ & $(.056)$ & $(.071)$ & $(.092)$ & $(.119)$ \\
\hline \multirow[t]{2}{*}{ Premie } &.$-(1) 20$ & $-.057 *$ & .005 & .028 & .107 \\
\hline & $(.014)$ & $(.032)$ & $(.041)$ & $(.053)$ & $(.068)$ \\
\hline$R^{2}$ & .222 & .239 & .148 & .213 & .206 \\
\hline $\mathrm{F}$ & $1.966 * *$ & 2.166 粦* & 1.203 & $1.874 *$ & $1.796 \%$ \\
\hline
\end{tabular}

** significant bij een niveau van 5 procent.

* significant bij een niveau van 10 procent

biectende onderneming heeft al vastgesteld wat er geboden moet worden zodat de overnameprijs opweegt tegen de verwachte symergie. Managers die streven naar optimale sinnergie zullen deze biedingstrategie volgen om te voorkomen dat men te veel betaalt. ondanks het risico dat men het bod niet accepteert.

Bii de markup pricing-hwpothese wordt een plotselinge stijging van de koers voor de aankondiging wel meegenomen in de biedingstrategie.
De onderhandelingspartners weten niet welke waardevolle informatic andere handelaren hebben. Een concurrent zou wellicht ook een bod willen doen op de aandelen van het doelwit. Dit gebrek aan informatie leidt tot cen aanpassing van het bod. Een hoge pre-bid premie en een gelijke markup-premie zal dan ook leiden tot een hogere overnamepremie. Wanneer men nict meer rekening houdt met de premie van de overname en men ten koste van

Figlul! 8

Pre-bid koersstijging van het doelwit
-40 dagen tot bod $\quad$ prebid runup + markup = overnamepremie
Wannecr het bod bekend wordt gemaakt na sluiting van de beurs wordt de slotkoers genomen van de dag na het bod.


Tabel 13: Regressieresultaten voor markup pricing.

In de regressie analyse zijn 87 bieders opgenomen. Door middel van dit model is de samenhang geanalyseerd voor de periode $(-40,+1)$ :

Premic $a+$ bRunup $-\mu$

In hel regressiemodel is a een constante en $\mu$ de storingsterm van de regressic. De variabele premic is de afhankelijke variabele (CAR $-40,+1)$ en is het CAR san het doelwit over de periode van veertig dagen vór het bod tot één dag na bekendmaking. De onathankelijke variabele runup is CAR (-40. - 1) vór bekendnaking van het geslatgde bod. De zinvolheid van de functie is getoetst door middel van een F-loets. In de tabel zijn lussen de haakjes de bijbehorende standiardfoulen opgenomen van de geschitte regressiecoëffiënten.

\begin{tabular}{|c|c|c|c|c|c|c|c|}
\hline Bieders & Aantal & $\begin{array}{l}\text { Rumulp coëfficiènt } \\
(b)\end{array}$ & T-lialarde & $\begin{array}{l}\text { Constante } \\
\text { (a) }\end{array}$ & $T$-riacarde & $R^{2}$ & F-waciarle \\
\hline Totaal & 87 & $\begin{array}{l}1.078 \% \\
(.146)\end{array}$ & 7.38 .5 & $\begin{array}{l}12.082 * \\
(1.858)\end{array}$ & 0.5() 2 & .388 & $54.536^{*}$ \\
\hline Negillief CAR & 42 & $\begin{array}{l}1.270^{*} \\
(.193)\end{array}$ & 6.581 & $\begin{array}{l}10.655 * \\
(2.440)\end{array}$ & 4.368 & .514 & $43.308 *$ \\
\hline Positief CAR & 45 & $\begin{array}{l}.807 * \\
(.226)\end{array}$ & 3.507 & $\begin{array}{l}14.786^{*} \\
(2.981)\end{array}$ & 4.961 & .226 & $12.296 *$ \\
\hline $\begin{array}{l}\text { Betaling in } \\
\text { atudelen }\end{array}$ & 41 & $\begin{array}{l}.992 * \\
(.192)\end{array}$ & 2.196 & $\begin{array}{l}7.675^{*} \\
(2.348)\end{array}$ & 3.268 & .406 & $26.60) 3 *$ \\
\hline $\begin{array}{l}\text { Betaling in } \\
\text { contanten }\end{array}$ & 19 & $\begin{array}{l}.632 * \\
(.288)\end{array}$ & 5.158 & $\begin{array}{l}19.845 * \\
(3.875)\end{array}$ & 5.121 & .211 & $+.822 *$ \\
\hline $\begin{array}{l}\text { Gemengde } \\
\text { betaling }\end{array}$ & 27 & $\begin{array}{l}1.397 * \\
(.264)\end{array}$ & 5.300 & $\begin{array}{l}14.596^{*} \\
(3.410)\end{array}$ & 4.280 & .529 & $28.087 *$ \\
\hline
\end{tabular}

* significant bij een niveau van 5 procent

alles cen overname wil bewerkstelligen is er sprake van een agency-probleem en met name Hubris lijkt dan een grote rol te spelen. Ondanks de voorgecalculeerde sinerglevoordelen denken de managers de benodigde extra winst te kunnen opbrengen die vereist is bij een hogere overnamepremic (Sirower, 1997). Een te hoge overnamepremie resulteert in een daling van de koers van de bieder. Deze daling is te zien als een reactie van de aandeelhouders die geen vertrouwen meer hebben in de symerglemogelijkheden van de acquirerende onderneming. Ondernemingen met een slechte biedstrategic bij acquisities lopen zelfs extra risico om zelf overnamekandidaat te worden (Mitchell en Lehn. 1990).

De samenhang tussen de pre-bid runup en de ovcrnamepremic is door middel van regressicanalyse onderzocht. Wanneer er geen correlatic is tussen de pre-bid runup en de premie, is er sprake van substitute pricing. In dit geval wijkt de biedende partij niet af van het voorgenomen bod en blijft de ovemamepremie constant. Bij markup- pricing zal er ecn sterk positieve samenhang zijn en lijken agency-problemen een rol te spelen. Door middel van het volgende regressiemodel zal de samenhang worden geanalyseerd.

$$
\text { (5) Premie }=a+\text { bRunup }+\mu
$$

De substitutiehypothese stelt dat de totale premie niet wordt beïnvloed door de pre-bid runup. zodat de regressiecoëfficiënt $b$ gelijk moet zijn aan nul. Wanneer de coëfficiënt $b$ gelijk is aan 1 is er sprake van markup pricing, waarbij de premic wordt aangepast aan de pre-bid runup. Bij een regressiecoëfficiënt $b$ tussen de nul en 1 is er sprake van partiële substitutie, waarbij maar een deel van de runup wordt toegevoegd aan de premie. In het regressiemodel is $a$ een constante en $\mu$ de storingsterm.

De regressieresultaten uit tabel 13 tonen aan dat markup pricing voor het total opgaat gezien de runup coëfficiënt van 1.078. Bij bicders met een negaticf rendement is deze coëfficiënt zelfs 1.270 , terwijl er bij bieders met een positief CAR 
sprake is van partiële substitutie gezien de hellingscoëfficiënt van .807 . Aan de hand van deze resultaten is op te maken dat lagere rendementen voor de bieder samengaan met een hogere runup coëfficiënt. De hypothese wordt dus geaccepteerd. Bij de bieders met een negatief CAR spelen agency-problemen een grotere rol dan bij de bieders met een positief CAR. Overigens bij betaling in contanten wordt de premie minder aangepast aan de runup dan bij aandelen en gemengde betalingen. Dit komt overeen met de verwachting dat de betaling in contanten een positieve bijdrage levert aan het CAR en samengaat met het synergie-motief. De gemengde betaling die meestal bestaat uit aandelen en contanten wordt het meest aangepast.

\subsection{Acquisitiemotieven van managers}

De ontwikkeling van het cumulatieve gemiddelde abnormale rendement geeft een beeld van de marktperceptie ten aanzien van een fusie. Dit cumulatieve rendement dat zowel voor het doelwit als de bieder is berekend vanaf het openbaar bod, kan mogelijk de motieven van managers om tot een fusie te komen verklaren.

De synergietheorie erkent managers als de belangenbehartigers van de aandeelhouders met als enig motief het creëren van meerwaarde. Bestuurders zullen alleen fuseren wanneer dit leidt tot een meerwaarde voor de aandeelhouders. Dit geldt zowel voor de managers van het doelwit als voor die van de bieder. In een door synergie gedreven overname is het doelwit in staat de overnameprijs op te voeren tijdens onderhandelingen omdat de meerwaarde van de synergie ook voor de aandeelhouders van de bieder zichtbaar is. Een positief CAR voor het doelwit is dus te verwachten en dit zal door de te voorspellen synergie ook voor de bieder gelden zodat beide rendementen ook positief gecorreleerd zijn met het totale rendement (Berkovitch en Narayanan,
1993). De agency-theorie stelt dat managers deels voor eigen gewin overnames doen ten koste van de aandeelhouders. Bij deze overnames zal alleen de CAR van het doelwit stijgen afhankelijk van het doorzettingsvermogen van de managers van de biedende onderneming. Het doelwit zal zich verzetten of de prijs opdrijven omdat men geen synergie verwacht en een deel van de winst die de managers van de biedende onderneming denkt te maken wil toe-eigenen, terwijl de aandeelhouders van de bieder zullen verkopen omdat men weinig rendement zal verwachten. Er zal bij agency-problemen een negatieve samenhang zijn tussen het CAR van het doelwit en dat van de bieder. Tevens kan de som van het CAR van beide ondernemingen samen negatief zijn wanneer de aandeelhouders van de bieders massaal het vertrouwen verliezen.

De hubris-theorie stelt dat managers zichzelf overschatten of een doelwit verkeerd op waarde schatten, waardoor zij overnames doen waarbij geen synergie te behalen is (Sirower, 1997). De intentie om synergie te behalen en de aandeelhouders te dienen is aanwezig, alleen wordt deze door zelfoverschatting of meetfouten van het management niet bereikt. De hubris-theorie gelooft niet in synergie en ziet een overname alleen als een transfer tussen eigenaren. Bij hubris verwacht men geen enkele correlatie tussen het CAR van het doelwit en het totale resultaat. Een hogere overnameprijs zal leiden tot een lager rendement van de bieder en andersom, maar het totale rendement zal ongeveer nul zijn.

Voor de duidelijkheid zal in onderstaande tabel de samenhang van het CAR en de bijbehorende hypotheses worden samengevat met de corresponderende theorie.

Uit de resultaten uit tabel 14 is op te maken dat hypothese 1 niet opgaat. De samenhang tussen het rendement van het doelwit en de bieder is namelijk voor alle drie regressies negatief. Van het synergiemotief lijkt dus geen

\begin{tabular}{llll}
\hline & $\begin{array}{l}\text { Samenhang CAR doelwit en } \\
\text { bieder }\end{array}$ & $\begin{array}{l}\text { Samenhang CAR doelwit en } \\
\text { totaal }\end{array}$ & Theorie \\
\hline Hypothese 1 & Positief & Positief & Synergie \\
\hline Hypothese 2 & Negatief & Negatief & Agency \\
\hline Hypothese 3 & Negatief & Geen & Hubris \\
\hline
\end{tabular}


Om aansluiting te vinden bij het onderzoek van Berkovitch en Narayanan (1993) wordt de periocie gekozen van lien dagen voor het bod tot vijf dagen na het bod. In de regressieanalyses zijn 88 fusies opgenomen. De lunctie is getoetst door middel van een F-toets. In de tabel zijn tussen haakjes de bijbchorende standaardfouten opgenomen van de geschatte regressiecoëffieiënten.

Samenhang tussen CAR doelwit en bieder.

\begin{tabular}{|c|c|c|c|c|c|c|c|c|}
\hline & $N$ & $\beta$ & Richting & $T$ & $\alpha$ & $T$ & $R^{2}$ & $F$ \\
\hline Allemaal & 88 & $\begin{array}{l}-.264 \% \\
(.160)\end{array}$ & - & -1.654 & $\begin{array}{l}228.908^{* * *} \\
(52.089)\end{array}$ & 4.395 & .030 & $2.736 \%$ \\
\hline $\begin{array}{l}\text { Alleen pos. Totaal } \\
\text { CAR }\end{array}$ & 62 & $\begin{array}{l}-.523 * * \\
(.222)\end{array}$ & - & -2.361 & $\begin{array}{l}352.257^{* * *} \\
(66.896)\end{array}$ & 5.266 & .084 & $5.57 .3 * *$ \\
\hline $\begin{array}{l}\text { Alleen neg. Totalal } \\
\text { CAR }\end{array}$ & 26 & $\begin{array}{l}-.615 * * \\
(.127)\end{array}$ & - & -4.857 & $\begin{array}{l}-128.160 * * \\
(47.837)\end{array}$ & -2.679 & .496 & $23.588^{* *}$ \\
\hline
\end{tabular}

Samenhang fussen CAR doelwit en fotad

\begin{tabular}{|c|c|c|c|c|c|c|c|c|}
\hline & $N$ & $\beta$ & Richting & $T$ & $\alpha$ & $T$ & $R^{2}$ & $F$ \\
\hline Allemaal & 88 & $\begin{array}{l}.734 * * \\
(.058)\end{array}$ & + & 12.688 & $\begin{array}{l}92.393 * * \\
(33.191)\end{array}$ & 2.784 & .649 & $160.989 * *$ \\
\hline $\begin{array}{l}\text { Alleen pos. Totaal } \\
\text { CAR }\end{array}$ & 62 & $\begin{array}{l}.852 * * \\
(.069)\end{array}$ & + & 12.396 & $\begin{array}{l}4.672 \\
(44.926)\end{array}$ & .104 & .716 & $153.665 *$ \\
\hline $\begin{array}{l}\text { Alleen neg. Totalal } \\
\text { CAR }\end{array}$ & 26 & $\begin{array}{l}.277 \\
(.237)\end{array}$ & Geen & 1.165 & $\begin{array}{l}93.023 \\
(72.238)\end{array}$ & 1.288 & .054 & 1358 \\
\hline
\end{tabular}

* significant bij een nivealu van 10 procent

** significant bij een niveau van 5 procent

sprake te zijn. Om te achterhalen welke motieven wel opgaan voor de Nederlandse situatie wordt gekeken naar de samenhang tussen de rendementen van het doelwit en het totaal. De regressies voor het geheel en die bij alleen een positief totaal CAR leveren een signifïcante positieve samenhang op. Voor deze twee regressies mocten dus de nulhypotheses die stellen dat er sprake is van agency of synergie worden verworpen. Alleen hypothese 3 lijkt op te gaan bij fusies met een negatief totaal CAR. De bèta voor deze groep is zeer laag en niet significant met een grote standaardfout, zodat de nulhypothese dat er sprake is van hubris niet wordt verworpen. Daar er nauwelijks samenhang is tussen het totale rendement en dat van het doelwit gaat voor deze groep hypothese 3 op. In de steekproef is er dus sprake van hubris bij 26 van de 88 bedrijven. Over de motieven bij andere fusies is via deze methode helaas niets te zeggen.

\section{Samenvatting en conclusie}

In het onderzoek was het totale rendement van de fusiepartners bij $60 \%$ in de onderzoeksperiode positief, met een totaal gemiddelde van $4,8 \%$. Vooral de methode van betaling heeft een grote invloed op de prestaties. De betaling in aandelen heeft een significante negaticve samenhang, terwijl de betaling in contanten een positieve bijdrage levert aan het totale rendement. Deze relatie tussen betalingsvorm en rendement komt overeen met eerdere onderzoeken uit Nederland en uit het buitenland.

Het rendement voor de bieders is minder gunstig. Net iets meer dan de helft $(52 \%)$ behaalt een positief resultaat in de onderzoeksperiode. Het gemiddelde resultaat is $0,94 \%$. Het resultaat wordt significant positief beinvloed door de betaling in contanten en negatief door de aanwezigheid van fusiegolven.

Bij het CAR van de doelwitten was $82 \%$ 
positief met een gemiddelde van $22.6 \%$. De verhouding tussen de marktwalarde van het eigen vermogen van de bieder en het doelwit levert een significante positieve bijdrage aan het rendement. Relatief grote bieders betalen blijkbaar hogere overnamepremies. De betaling in aandelen wordt nict echt gewaardeerd door aandeelhouders van het doelwit gezien de grote negaticve bijdrage aan het $C A R$.

Deze resultaten zijn alanmerkelijk positiever dan die eerder hierover zijn gepubliceerd. Een verklaring hiervoor kan zijn dat $93 \%$ van de fusies horizontaal van richting waren waardoor er ecrder synergie werd gecreëerd dan bij verticale of diagonale fusies.

Ten aanzien van de fusiemotieven en de achterliggende theorieën blijkt dat de markt meer gelooft in mogelijke sinergie bij de nieuwe combinatic. wanneer de bieder de overname betaalt in contanten. Niet alleen de aandeellouders van de bieder hebben hier voorkeur voor. maar ook die van het doelwit. De betaling in aandelen wordt gemiddeld slecht gewalrdeerd door de andeelhouders van de bieder en doet het rendement dan ook dalen.

In een periode van veel overnames (fusiegolf) is het rendement voor bieders significant lager dan in andere periodes, zodat gesteld kan worden dat de speltherrie lijkt op te gaan voor de Nederlandse situatie.

Er zijn aanwijzingen gevonden voor de stelling dat markup pricing een negatieve bijdrage levert aan het rendement van de bieders in Nederland, zoals ook gebleken is in de Amerikaanse markt. Hoewel markup pricing voor het totaal opgaat. blijkt dat de regressiecoëfficiënt bij bieders met een negatief rendement significant hoger is dan bij bieders met een positief rendement. Bij bieders met een positief rendement is er sprake van partiële substitutie. Markup pricing kan dus gezien worden als een agenci-probleem. Deze biedingstrategie komt vooral voor bij de betaling van de overname met aandelen of in een gemengde vorm. Dit komt overeen met de uitkomsten, waruit blijk dat de betaling in contanten een positieve bijdrage levert aan het CAR en samengaat met het sinergie-motief. Middels de analyse naar de correlatie van de verschillende rendementen komt nar voren dat dertig procent van de acquisities kan worden toegerekend aan hubris. Overschatting van de waarde van het doelwit of zelfoverschatting van de managers van een biedende onderneming speelt dus net als in Amerika een betekenisvolle rol in Nederland.

\section{I T E R A T U U R}

Berkovitch, E and M.P. Narayanan, (1993), Motives for Takeovers: An Empirical Investigation, Journal of Financial and Quantative Analysis, 28, pp.347363

Bosveld, R., P. Meyer, and T. Vorst, (1997), Takeover Premiums In The Netherlands, opgenomen in $\mathrm{J}$. Spronk e.a., Financieringen en beleggingen, deel 20, Erasmus Universiteit Rotterdam, pp. 125-158

Brown, S.J. and J.B. Warner, (1980), Measuring Security Price Performance, Journal of Financial Economics, 8, pp. 205-258.

Bruin, D. de en R.A.I.van Frederikslust, (1994), Financiële resultaten van fusies en acquisities, Fusies en Acquisities, J.C.K.W Bartel, e.a., Houten, Stenfert Kroese, pp. 99-122

Duijn, J.J. van, (1992). Fusies and overnames en de aandelen belegger, Fusies en Overnames, J.J. van Duijn, e.a., Schoonhoven, Academic Service, pp. 19-34.

Eriksson, J., P. Högfeldt and J. Spens, (1998), Bidder Share Price Reactions Following Takeover Announcements, paper prepared for the 25th Anniversary Meeting of the European Finance Association, Paris

Franks, J.R. and R.S. Harris, (1989), Shareholder Wealth Effects of Corporate Takeovers, Journal of Financial Economics, 23, pp. 1513-1525.

Hansen, R., (1987), A Theory for the Choice of Exchange Medium in Mergers and Acquisitions, Journal of Business, 60, pp. 75-95.

Healy, P., K. Palepu, and R.S. Ruback, (1992), Do Mergers Improve Corporate Finance?, Journal of Financial Economics, 31, pp. 135-175.

Jong H.W., de, (1998), Fusiegolven: theorie en empirie, Tijdschrift voor Bedriffsadministratie. december nummer 1218, pp. 446-451.

Kemna, A., T. Kloek, en A. Pieterse, (1994), Een empirische verklaring voor de vermogensstructuur van Nederlandse ondernemingen, Maandblad voor Accountancy en Bedriffeconomie, december, pp. 737-750

Keynes, J.M., (1936), The General Theory of Employment, Interest, and Money, London, Macmillan. 
Mitchell, M.L. and K. Lehn, (1990), Do Bad Bidders Make Good Targets, Journal of Political Economy, 98, pp. 372-398.

Mitchell, M.L and J.H. Mulherin, (1996), The impact of industry shocks on takeover and restructuring activity, Journal of Financial Economics, 41, pp.193-229.

Morck, R., A. Schleifer, and R. Vishny, (1990), Do managerial Objectives Drive Bad Acquisitions?, Journal of Finance, 45, pp. 31-48.

Mueller, D.C., (1989), Mergers: Causes, Effects and Policies, International Journal of Industrial Organisation, 7, pp. 1-10.

Myers, S. and N.S. Maljuf, (1984), Corporate Financing and Investment Decisions When Firms Have Information That Investors Do Not Have, Journal of Finacial Economics, 13, pp. 187-221.

Roll, R., (1986), The Hubris Hypothesis of Corporate Takeovers, Journal of Business, 59, pp. 197-216. Schenk, H., (1996), Bandwagon Mergers, International Competitiveness and Government Policy, Empirica,
Journal of Applied Economics and Economic Policy, 23, pp. 255-278.

Schenk, H., (1994), Fusies als economisch en strategisch verschijnsel; reële of ogenschijnlijke paradoxen, Fusies en Acquisities, J.C.K.W. Bartel, e.a., Houten: Stenfert Kroese, pp. 33-90.

Schwert, W.G., (1994), Markup pricing in mergers and acquisitions, Journal of Financial Economics, 41 (1996), pp. 153-192.

Sirower, M.L., (1997), De valstrik van synergie, eerste editie in Nederland, Amsterdam: Contact.

Weston, J.F. and T.E. Copeland, (1992), Managerial Finance, The Dryden Press, New York.

\section{NOOT}

1 De inflatiecorrectie is uitgevoerd door middeling over de periodes rekening houdend met de prijsindexcijfers in de onderzoeksperiode. 